\title{
Uneven Data Quality and the Earliest Occupation of Europe- the Case of Untermassfeld (Germany)
}

\author{
Wil Roebroeks ${ }^{1}$ (D) \\ Sabine Gaudzinski-Windheuser ${ }^{2,3}$. \\ Michael Baales $^{4,5} \cdot$ Ralf-Dietrich Kahlke ${ }^{6}$
}

(C) The Author(s) 2017. This article is an open access publication

\begin{abstract}
The database regarding the earliest occupation of Europe has increased significantly in quantity and quality of data points over the last two decades, mainly through the addition of new sites as a result of long-term systematic excavations and large-scale prospections of Early and early Middle Pleistocene exposures. The site distribution pattern suggests an ephemeral presence of hominins in the south of Europe from around 1 million years ago onward, with occasional short northward expansions along the western coastal areas when temperate conditions permitted. From around 600,000-700,000 years ago, Acheulean artefacts appear in Europe and somewhat later hominin presence seems to pick up, with more sites and now some also present in colder climatic settings. It is again only later, around 350,000 years ago, that the first sites show up in more continental, central parts of Europe, east of the Rhine. A series of recent papers on the Early Pleistocene palaeontological site of Untermassfeld (Thuringia, Germany) makes claims that are of great interest for studies of earliest Europe and are at odds with the described pattern: the papers suggest that Untermassfeld has yielded stone tools and humanly modified faunal remains, evidence for a 1 million years old hominin presence in European continental mid-latitudes, and additional
\end{abstract}

Wil Roebroeks

w.roebroeks@arch.leidenuniv.nl

1 Faculty of Archaeology, Leiden University, Leiden, The Netherlands

2 MONREPOS Archaeological Research Centre and Museum for Human Behavioural Evolution, Schloss Monrepos, Neuwied, Germany

3 Institute of Ancient Studies, Johannes Gutenberg University Mainz, Mainz, Germany

4 LWL-Archäologie für Westfalen, Außenstelle Olpe, Olpe, Germany

5 Institute for Pre- and Protohistory, Faculty of History, Ruhr-University Bochum, Bochum, Germany

6 Senckenberg Research Station of Quaternary Palaeontology, Weimar, Germany 
evidence that hominins were well-established in Europe already around that time period. Here, we evaluate these claims and demonstrate that these studies are severely flawed in terms of data on provenance of the materials studied and in the interpretation of faunal remains and lithics as testifying to a hominin presence at the site. In actual fact, any reference to the Untermassfeld site as an archaeological one is unwarranted. Furthermore, it is not the only European Early Pleistocene site where inferred evidence for hominin presence is problematic. The strength of the spatiotemporal patterns of hominin presence and absence depends on the quality of the data points we work with, and database maintenance, including critical evaluation of new sites, is crucial to advance our knowledge of the expansions and contractions of hominin ranges during the Pleistocene.

Keywords Early Pleistocene $\cdot$ Lower Palaeolithic $\cdot$ Europe $\cdot$ Hominin dispersal $\cdot$ Bone modifications $\cdot$ Pseudo-artefacts

\section{Introduction}

\section{The Earliest Occupation of Europe}

At the end of the Pleistocene, human populations had colonised almost all corners of the world, in a process of range expansion from Africa which had started minimally by 1.8 million years ago. The spatiotemporal patterns of the traces of hominin presence and absence can inform on hominin adaptability and the dynamics of range expansions and contractions in the face of environmental changes of the Pleistocene. Europe has the best documented record in this regard, as a result of its long and intensive research history. The record that is more interesting as this cul de sac of the Eurasian landmass is large enough to display ecological differences from south to north and from west to east, which may have formed ecological clines and barriers during range expansion. Furthermore, a rich database exists on Pleistocene climatic and environmental variability in this part of the hominin range which allows interpretation of patterns of hominin colonisation against the background of fine-grained environmental changes (Ashton and Lewis 2012; Dennell 2003; Dennell et al. 2010; Kahlke et al. 2011; MacDonald et al. 2012; Roebroeks 2006).

Our database regarding the earliest occupation of Europe has increased significantly in quantity and quality of data points over the last two decades, mainly through the addition of new sites as a result of long-term systematic excavations (e.g. at Atapuerca, Spain (Bermúdez de Castro et al. 2011; Carbonell et al. 1995), with late Early Pleistocene finds, dating to more than $800 \mathrm{ka}(1 \mathrm{ka}=1000$ years before present $)$ and large-scale prospections of Early and early Middle Pleistocene exposures. A good example of such prospection work is the case of the Cromer Forest Bed formation in East Anglia, UK (Parfitt et al. 2005, 2010), which yielded evidence for surprisingly early (up to c. $800 \mathrm{ka}$ ) - and possibly short-term - range expansions into northwestern Europe, up to $53^{\circ}$ north.

The hominin occupation of northwestern Europe before $\sim 500-600 \mathrm{ka}$ was on current evidence (Ashton and Lewis 2012; MacDonald et al. 2012; Moncel et al. 2017) highly sporadic and probably the result of temporary range expansions of southern (circum-Mediterranean) populations when conditions ameliorated and 
permitted short northward movements, probably along its western coastal margins (Cohen et al. 2012; MacDonald 2017). In general terms, in the whole of Europe, there still seems to be a threshold for longer-term hominin settlement at around 500-600 ka, with a marked increase in the number of sites (now not only during temperate climatic intervals but also during colder and drier phases) and the sizes of the assemblages. It is also from around 600-700 ka onward that we observe the first presence of Acheulean tools in Europe (Moncel et al. 2015), about a million years later than their first appearance in eastern Africa (Lepre et al. 2011). The first occupants of Europe seem to have done without handaxes, the earliest European assemblages only comprising stone flakes, rarely retouched, cores, and core-like tools, with a lack of standardised design and usually with limited modification only (Moyano et al. 2011; Ollé et al. 2015; Parfitt et al. 2010). This gives special importance to the study of the geological context of inferred early sites: rocks can fracture naturally and edges can be modified by natural processes in sediments such as cryoturbation, transport, and volcanic activities, and a wide variety of such processes has been documented to mimic hominin modification and to produce "artefact-like" geofacts (Gillespie et al. 2004; Lubinski et al. 2014; Nash 1993; Peacock 1991; Raynal et al. 1995; Warren 1914, 1920; Wiśniewski et al. 2014) (see also below, "Discussion”). Interestingly, the emergence of the Acheulean signal in southern (Villa 2001) as well as northwestern Europe from 600 to $700 \mathrm{ka}$ (Moncel et al. 2013, 2015; Pereira et al. 2015) onward is in the same time range as the current estimate for the beginning of the Neandertal lineage (Meyer et al. 2016).

In the second half of the Middle Pleistocene, from around $350 \mathrm{ka}$ onward, archaeological sites are no longer limited to the western (Atlantic) and southern (Mediterranean influenced) regions of Europe but also show up in its more continental areas, east of the river Rhine catchment area (Cohen et al. 2012; Conard et al. 2015; Kahlke et al. 2011): a range expansion into more challenging environments that might be related to the development of new strategies for survival (Hosfield 2016), including the introduction of fire as a fixed part of the hominin technological repertoire (MacDonald 2017; Roebroeks and Villa 2011; Shimelmitz et al. 2014).

The authors of two recent studies of faunal material attributed to the late Early Pleistocene palaeontological site of Untermassfeld (Germany) (Landeck and Garcia Garriga 2016, 2017) make two claims that are of great relevance in the context of the study of the earliest occupation of Europe. Firstly, they reiterate their previous (Garcia Garriga et al. 2013; Landeck 2010; Landeck and Garcia Garriga 2015) assertion that the Untermassfeld site has also yielded lithic artefacts and that hence Central Europe saw already a hominin presence about 1 million years ago. Secondly, they also claim to have identified in the faunal remains from the site numerous evidence of hominin butchering activities, such as cut marks and intentional hammer stone-related bone breakage, and identify exploitation patterns which suggest year round primary access to preferentially bison, horse, deer, and megafauna species. The authors conclude that the stone tools and the humanly modified faunal remains from Untermassfeld provide evidence for the earliest hominin presence in European continental mid-latitudes at about $50^{\circ}$ north. Together with the evidence from inferred contemporaneous sites such as Vallparadis (Spain) (Martínez et al. 2010) and Le Vallonet (France) (de Lumley 1988; Michel et al. 2017), they see this as additional evidence that humans were wellestablished in Europe already 1 million years ago. If these claims are substantiated, the 
Untermassfeld site, a striking outlier in the geographical distribution of early Palaeolithic sites (Rolland 2013; Wiśniewski et al. 2014) thus far and at odds with the spatio-temporal pattern described above, would indeed be a very interesting occurrence. The far-reaching implications of these claims warrant an in-depth assessment of the arguments presented by these authors (Garcia Garriga et al. 2013; Landeck 2008, 2010; Landeck and Garcia Garriga 2015, 2016, 2017).

The increase of the European archaeological record (see below: Discussion) has opened possibilities to study range expansions and contractions of hominin populations, including regional extinctions, during the Pleistocene (Bermúdez de Castro et al. 2016; Dennell et al. 2011; Hublin and Roebroeks 2009; MacDonald et al. 2012) and has allowed rephrasing the question "When was Europe first occupied?" into "How often was Europe abandoned after hominins first entered it?" (Dennell et al. 2011). Key to such studies is establishing the strength of the spatiotemporal patterns we work with. When studying the early occupation history of any given area, palaeoanthropologists' first task is to critically assess the strength of the evidence for a presumed hominin presence, as well as to provide a solid framework for bracketing the age of such finds, i.e. lithics and fossils. The quality of these data determines the quality of the resulting spatiotemporal patterns of hominin presence and absence and hence the quality of the hypotheses developed to interpret these patterns. In a discipline in which the data about the exact provenance and geological context of finds is usually only obtainable through publications, researchers are banking heavily on the quality of fieldwork and of the resulting publications, including detailed description of provenance data and reproducibility of analyses carried out in the laboratory, which also entails accessibility of the finds at stake.

In this paper, we will give a brief description of the Untermassfeld site, including its history of systematic excavations and analyses and its geological genesis. We will then evaluate the strength of the recent claims for a hominin presence at the site at the end of the Early Pleistocene in terms of lithics and faunal remains (Garcia Garriga et al. 2013; Landeck 2008, 2010; Landeck and Garcia Garriga 2015, 2016, 2017) and end with a brief discussion of the current debate on the early hominin occupation of Europe.

\section{The Untermassfeld Site: Research History and Geological Setting}

The Early Pleistocene fossil site of Untermassfeld, near the town of Meiningen in Southern Thuringia (Central Germany), was discovered in January 1978 and has since the discovery been the focus of continuous systematic fieldwork, carried out exclusively by the Senckenberg Research Station of Quaternary Palaeontology, Weimar (formerly the Institute of Quaternary Palaeontology, Weimar) (Fig. 1). So far, the field seasons include a total of 90 months of fieldwork (status as of January 1th, 2017). The three-dimensionally fine scale documented excavations (Fig. 1) have produced a total of 17,882 catalogued specimens or specimen series including 14,224 fossil remains of large mammals from a total of $650 \mathrm{~m}^{2}$ (status as of January 1, 2017), excavated to a maximum depth of $5.50 \mathrm{~m}$ below ground level. From the very beginning of the excavations up to the most recent field season in 2017, all excavated sections were microstratigraphically (scale 1:10) documented under the direction of one of the authors (R.-D. K.). Apart from the fossil bearing fluviatile sands, no further find horizons were recorded. Depending on the find density and conservation status, fossils were taken out 


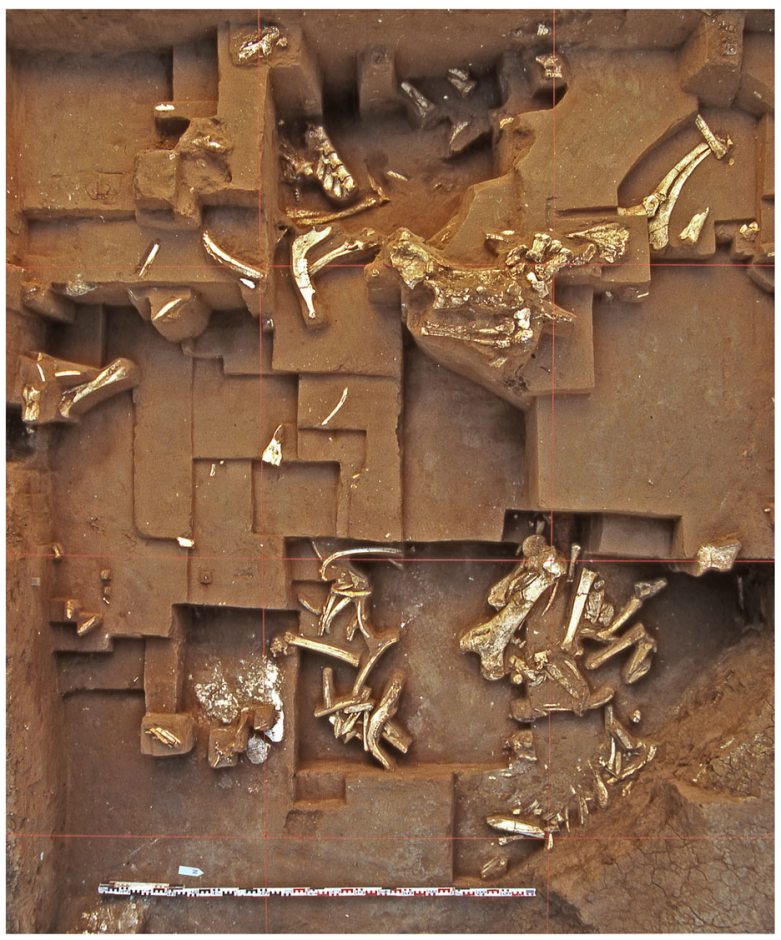

Fig. 1 Untermassfeld research excavation (August 2002), excavation area with grid squares 21-24, 47-50, 154-158, and 1.18-2.12 m below site 0-level, exposed finds of predominantly Bison menneri, Dama nestii vallonnetensis, Eucladoceros giulii, and Hippopotamus antiquus

of the embedding sediment as individual pieces, removed in plaster jackets to ensure stability, or lifted by crane in large blocks from the excavation site. During the fieldwork free periods, the active sections of the site were covered with 1 tonne steel plates measuring $2 \times 4 \mathrm{~m}$, to minimise unauthorised access by third parties.

The fossil assemblage recovered at Untermassfeld represents the most complete vertebrate record of the late Early Pleistocene in the Western Palaearctic and includes numerous newly discovered taxa. Importantly, this fauna has provided the base for establishing the Epivillafranchian as an independent biochron for the time period 1.2 to 0.9 Ma in the Western Palaearctic (Kahlke 2007, 2009; Kahlke et al. 2011). Untermassfeld is studied by an interdisciplinary research group, with 49 researchers from 31 institutions in 12 countries involved (status as of January 1, 2017; www.senckenberg.de/root/index. php?page_id=2915. See Kahlke 1997, 2001a, b, 2006 for detailed information on research history and the present results of this interdisciplinary research group).

At Untermassfeld, the eastern slope of the Werra river valley cuts Triassic formations. Upstream of the fossiliferous site, in its immediate vicinity as well as in the subsoil, Middle Triassic calcareous rocks crop out (Fig. 2). This so-called Muschelkalk formation occasionally contains thin layers of silicified greyish to greyish-brown chert. Triassic limestone and chert are frequently found in Early Pleistocene gravels cut by the fossiliferous layers of the site, as well as in all other Pleistocene fluviatile deposits of the middle Werra valley. The lithological characteristics of the sands of the Untermassfeld fossil site demonstrate that they are floodplain deposits, accumulated 


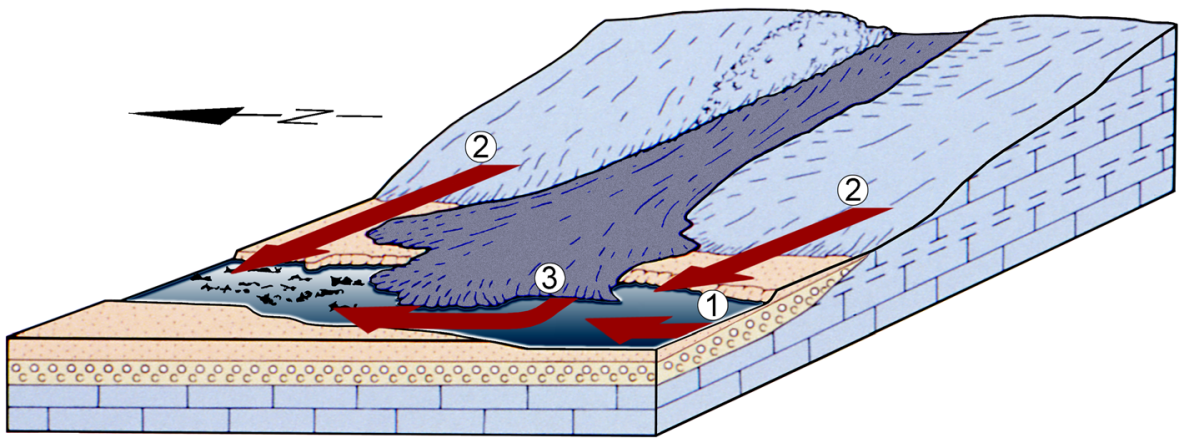

Fig. 2 Schematic reconstruction of the Untermassfeld area during formation of the site: geological sequence with Middle Triassic carbonates (brick symbol), fluviatile gravels (circles) and sands (dots), and mass accumulation of carcass remains under the lee of an extended clastic mudflow fan (dashed). Arrows indicate the origin of limestone and chert rocks transported into the bone bearing sands. 1 From the upper reaches of the Werra River and eroded subsoil of the river, 2 from adjacent slopes of the valley, 3 from the mudflow fan within the site itself (drawing based on Kahlke 2006)

as a result of powerful high flood events (Ellenberg and Kahlke 1997; Kahlke 2006). The deposition of the vertebrate and non-vertebrate faunal assemblage at the site occurred under the lee of an extended clastic mudflow fan that had poured from the adjacent valley slope into the river channel (Fig. 2). Upstream of the excavation site, a narrow part of the valley caused strong turbulences as well as a rapid rise of the upstream water level.

During the formation of the find bearing deposits, reconstructed with data obtained during excavations and corresponding continuous geological surveys, rocks of Triassic limestone and chert were transported into the fossiliferous deposits from various sources: the upper reaches of the river, the slopes of the valley, the eroded and reworked subsoil of the site, and the clastic mudflow fan within the site itself (Fig. 2). The redeposition of Triassic material took place by means of high-energy processes that caused mechanical splintering and breakage of the corresponding rocks.

The Untermassfeld project has from its very beginning explicitly taken into consideration a possible presence of traces of hominin activities (Kahlke 1997, 2006) and lithics were continuously inspected for traces of hominin modification (see Plate 12.2 in Ellenberg and Kahlke 1997), as were the faunal remains from the site (the first director of the excavations at the site, H.-D. Kahlke, was trained as an archaeologist and had worked at many Palaeolithic sites, including Zhoukoudian in China (Hemmer 2006)). However, as repeatedly emphasised in publications on the site, no traces of a hominin presence whatsoever could be identified thus far (Kahlke 2006; Kahlke and Gaudzinski 2005). How then, does the material presented by Landeck and colleagues (Garcia Garriga et al. 2013; Landeck 2008, 2010; Landeck and Garcia Garriga 2015, 2016, 2017) fit in the Untermassfeld evidence?

\section{Materials and Methods}

In order to evaluate the recent claims regarding a hominin presence at the site, we studied the material published in the articles at stake, as far as that was available: a 
small sample of faunal remains and 11 lithic objects (why the examined sample is so small will be explained below). Zooarchaeological analyses of the faunal material by S.G.-W. focussed on the identification of surface modifications: in order to evaluate the claims made by Landeck and Garcia Garriga, the identification of hominin induced modifications in the form of cut marks and traces of marrow extraction was the focus of our attention. Bone surfaces were studied using a Leica reflected-light microscope with a magnification of up to $32 \times$. All traces were registered per bone and recorded by anatomical position. Diagnostic criteria were used to identify hominin-induced cut marks (Bunn 1982; Potts and Shipman 1981) and anthropogenic fractures (Blumenschine and Selvaggio 1988, 1991; Domínguez-Rodrigo and Barba 2006). M.B. and W.R. studied the lithics, in order to assess the artificial character of the finds, using hand lenses with magnification up to $\times 12$. Besides basic measurements, types of raw material, character and numbers of negative scars, presence/absence of striking platforms, and cortical presence were studied.

To explain why the available sample of faunal remains and lithic finds is so small, we need to briefly discuss the provenance of the material published by Landeck, Garcia Garriga, and colleagues as well as the information on where it is deposited for other researchers to access.

The sample presented by the referred authors (Garcia Garriga et al. 2013; Landeck 2008, 2010; Landeck and Garcia Garriga 2015, 2016, 2017) allegedly consists of a number of 419 faunal remains and 256 stone objects. The provenance of the overwhelming bulk of the faunal and lithic materials however is unclear, as at no time in the site's long excavation history, any other regular excavations or other types of find recovery occurred. Landeck, Garcia Garriga, and their co-authors were never involved in the Senckenberg Untermassfeld research team, not in the fieldwork nor in laboratory analyses of the material.

A recent paper in the Journal of Human Evolution describes faunal remains said to come from the Untermassfeld site. Photos of the excavation which appear in their publication (Landeck and Garcia Garriga 2016) were taken by a "tourist" (their Fig. 1) and by unknown persons who somehow gained access to the protected site area (their Fig. 2, right). Regarding the origin of the published finds (Landeck and Garcia Garriga 2016), the authors claim to have studied Untermassfeld faunal remains present in a "Schleusingen collection" $(2016,58)$, assembled during "archaeological rescue operations at the Untermassfeld site in the late 70s and early 80s." However, no such operations ever occurred at the site, and the Schleusingen collection either does not exist or is only known, and accessible, to Landeck and Garcia Garriga. Indeed, even the claim that the Untermassfeld site is the actual source of all the bone fragments is questionable. However, one fragment published by Landeck and Garcia Garriga (2016, Fig. 6c), the distal portion of a right metacarpal bone of Dama nestii vallonnetensis, does indeed originate from the Untermassfeld excavation site: it was stolen from the site between 12:00 $\mathrm{h}$ on the 29th of May and 12:30 $\mathrm{h}$ on the $2 \mathrm{nd}$ of June, 2009, i.e. during the Pentecost 2009 weekend. It was broken when forcibly removed from a bone concentration (square Q 30; Fig. 3a). Fragments of the proximal bone portion remaining in the layer (Fig. 3b) were later recovered during subsequent official Senckenberg excavation work and then glued, preserved, and catalogued (Senckenberg Research Station of Quaternary Palaeontology, Weimar, Untermassfeld Collection IQW 2010/30 740 (Mei 29 902)). Both the theft and 

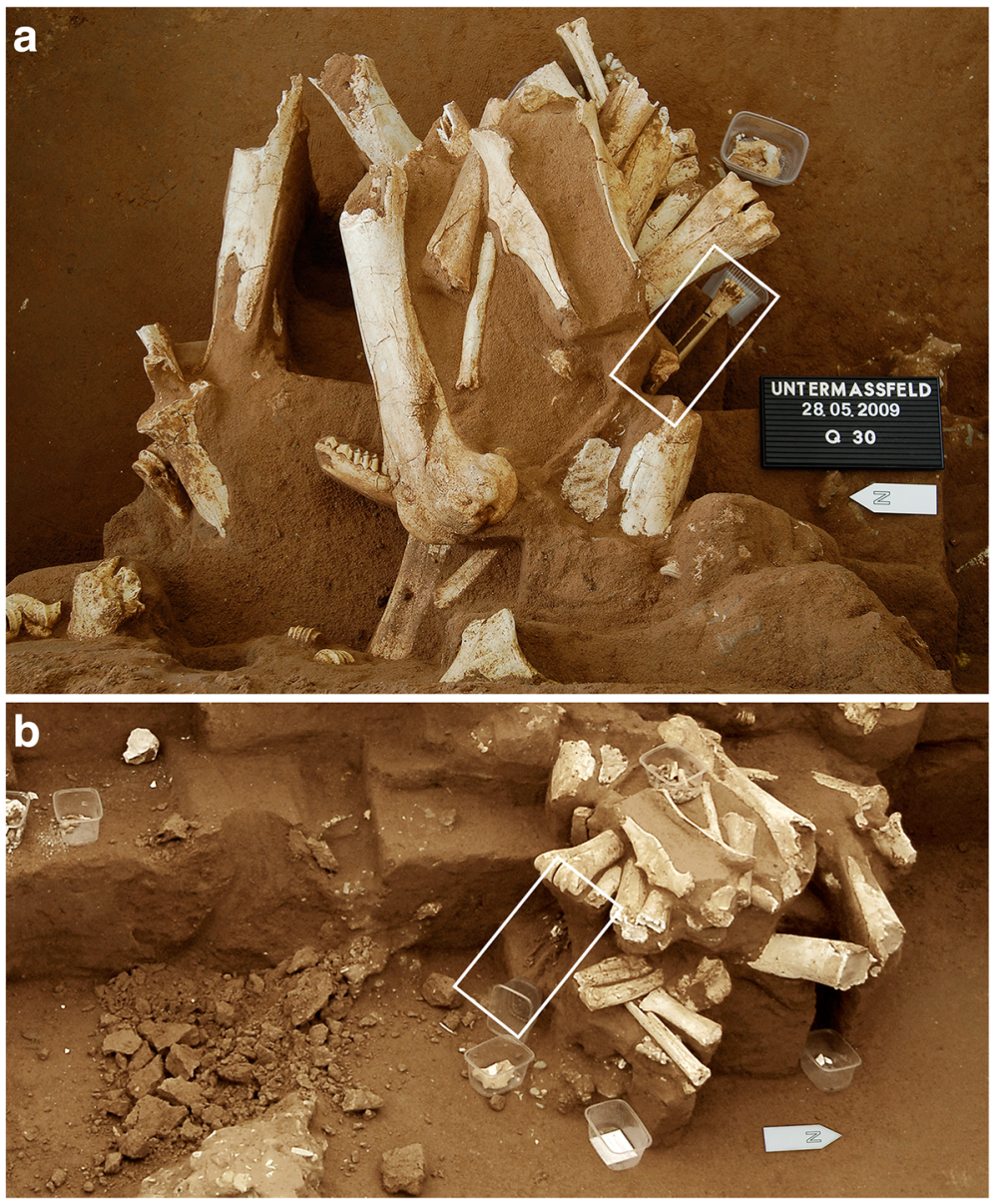

Fig. 3 Untermassfeld research excavation covered by excavation tent: a Undamaged polyspecific bone concentration exposed in square 30 (seen from above) with complete right metacarpal bone (rectangle) of a medium sized deer (Dama nestii vallonnetensis), 28th of May, 2009. b Damaged excavation view (picture of the same concentration but taken from different angle), distal part of the deer metapodial broken off, splintered proximal part still within the sediment block (rectangle), 2nd of June, 2009

vandalism were reported to the responsible police authority (case number KPI Suhl/1707-008127-09/1) and corresponding investigations were carried out by the Meiningen public prosecution office (case number 560 UJs 11134/09 60). Thefts and illegal excavation activities at the site had to be reported to the police also in the years 2002, 2006, 2007, 2009, 2010, 2011, and 2012.

Five years later, in March 2014, two packages were anonymously delivered to the Natural History Museum Schloss Bertholdsburg, Schleusingen (Thuringia). Along with an accompanying anonymous letter, the packages contained bone and rock material allegedly originating from the Untermassfeld site (personal communication by $\mathrm{R}$. Werneburg, director of the Schleusingen museum, to R.-D. K. on the 22nd of July, 2014). Information on the circumstances surrounding the recovery of these specimens or their find locations was not included. One of the packages contained the abovementioned metapodial fragment from $D$. nestii vallonnetensis. This fragment, according 
to Landeck and Garcia Garriga (2016) part of an assemblage recovered in the late 1970 s and early 1980s, was still in the ground decades later and stolen as an incomplete fragment from a 2009 excavation area (Fig. 3). Figure 4 shows the regained distal metapodial fragment refitted to the proximal portion of the same skeletal element, recovered by the Senckenberg excavators. The whereabouts of the freshly broken, but still missing, portions of the bone remain unknown. The packages delivered to the Natural History Museum Schloss Bertholdsburg were transferred to the Senckenberg Research Station at Weimar. In these packages, further bone fragments published by Landeck and Garcia Garriga (2016, Figs. 3b, 4a, e, 5a, e, 6d, 7d, g, and 8a) were identified, in total 10 out of the 36 illustrated in their Journal of Human Evolution paper.

Given their facies, i.e. colour, degree of mineralization, and brittleness, it is likely that these bones, like the deer metacarpal, also come from the Untermassfeld site. If we assume that the bone fragments in the packages $(n=64)$ were part of the assemblage studied by Landeck and Garcia Garriga (2016: Table 1), the whereabouts of 355 pieces, i.e. $84 \%$ of the material allegedly studied, are presently unknown.

The provenance as well as the whereabouts of the majority of the published lithics are totally unclear: Garcia Garriga et al. (2013) claim to have studied 256 lithic objects from Untermassfeld, without any documentation of where and how these were obtained. An online document from 2008 (Landeck 2008) simply states that "Nearly all of the lithic implements are very small and apparently have been overlooked by the excavating palaeontologists." In a published exchange between M.B. (Baales 2014) and Landeck and Garcia Garriga (2015) regarding the unclear provenance of the rock fragments, Landeck and Garcia simply state that the lithics which they interpret as artefacts "... were recovered in situ from the Early Pleistocene sediments ... which also included the large mammal remains" (Landeck and Garcia Garriga 2015)—without any information on the location of the finds and without any form of description of a relevant section whatsoever. It is also unclear where this material is deposited. Landeck (2008) states that "Objects are handed over to the excavator Dr. R.D. Kahlke (Forschungsstation für Quartärpaläontologie, Senckenberg-Institut Weimar) and are stored at the Thüringer Landesamt für Denkmalpflege (Weimar)." According to a later publication (Landeck 2010), "a small selection of specimens is preserved at the Thüringer Landesamt für Denkmalpflege (Weimar)" (2010: 1230). The Thüringer Landesamt für Denkmalpflege, however, does not hold lithics from Untermassfeld (pers. comm. email Dr. T. Schüler, Landesamt für Denkmalpflege und Archäologie, Weimar, September 6th 2016) and no lithics were handed over to the Senckenberg Research Station of Quaternary Palaeontology. However, the two packages with the faunal remains delivered to the Schleusingen museum in 2014 contained 11 small rock fragments, all of which we identified as having been published as artefacts by Garcia Garriga et al. (2013: their Figs. 5a, c-e, 6a-d, and 7c-e).

In summary, it must be concluded that the information given by Landeck and Garcia Garriga (Garcia Garriga et al. 2013; Landeck and Garcia Garriga 2016) about the origins of the published lithic and faunal specimens is dubious, incomplete, and at in one case demonstrably false. Furthermore, the publications provide no and/or incorrect data on where the studied material is stored and hence where it can be accessed by other researchers. For our analysis, the only material we had at our disposal was the material 


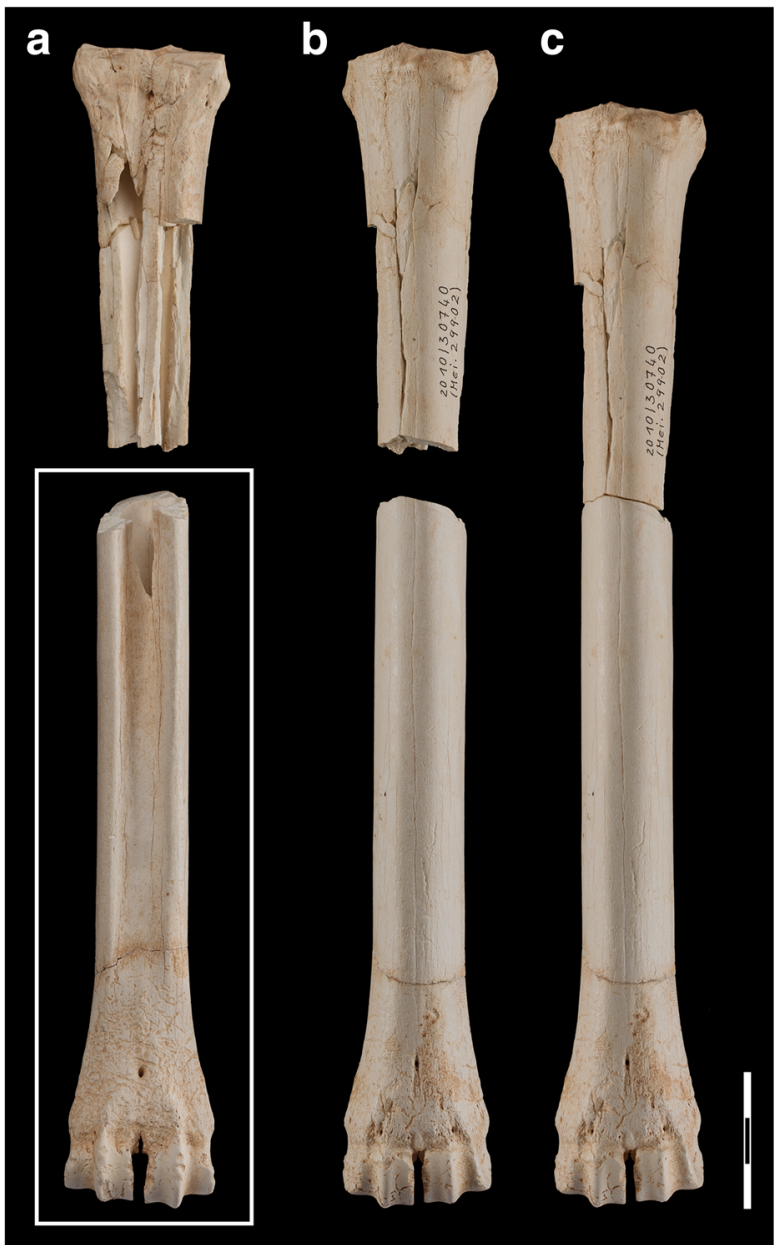

Fig. 4 Untermassfeld, right metacarpal bone of Dama nestii vallonntensis: a-b Proximal part of the bone: damaged during illegal activities, recovered during an official excavation, then prepared and catalogued. a-b Distal part of the bone: broken off from an exposed polyspecific bone concentration in 2009 (rectangle; cf. Fig. 3a), published by Landeck and Garcia Garriga (2016, Fig. 6c) and anonymously transferred to the Natural History Museum Schleusingen. c Excavated and stolen parts of the metapodial re-joined (now in the Untermassfeld collection of Senckenberg Weimar) (scale $3 \mathrm{~cm}$ )

in the anonymously delivered packages, momentarily stored at the Senckenberg Research Station of Quaternary Palaeontology at Weimar.

\section{Results}

\section{Faunal Remains}

Landeck and Garcia Garriga infer hominin presence at the site on the basis of the presence of cut marks and traces of intentional hammerstone-related bone breakage on the bones of large mammals. This is interpreted as indicative of regular primary access 

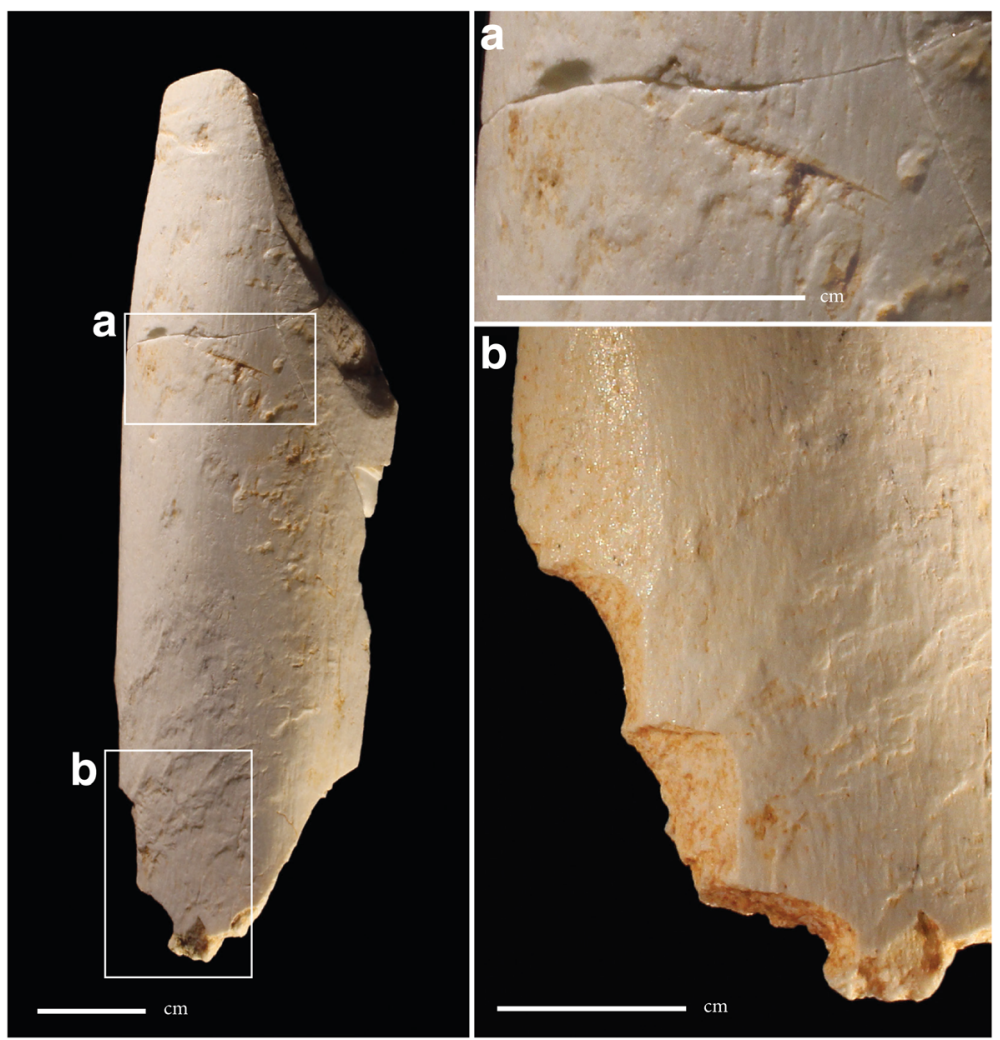

Fig. 5 Femur fragment of a medium-sized mammal. a Bone damage interpreted by Landeck and Garcia Garriga (2016) as a defleshing cut mark, overlapped by a tooth mark, indicating primary access to carcasses by hominins (Landeck and Garcia Garriga 2016, p. 58, 63, Fig. 3b). Examination of the bone fragment, however, shows that the surface damage is characterised by blunt, undefined shoulders that merge into the surrounding bone surface. The modification starts as a very shallow striation in a modern break and is interrupted by a modern planar removal of the bone surface. The lower left part of the modern planar surface removal is filled with red sediment, as well as the deeper section of the modification. b Carnivore damage is evident on the edges of the bone fragment

to the carcasses of large mammals, butchering of complete animals, and exhaustive exploitation by marrow processing. The bone fragments indeed were found to display surface modifications, but none of these are convincing in terms of manipulation by Pleistocene hominins. The problems that are apparent with the identification of presumable cut marks published by Landeck and Garcia Garriga are manifold. The authors for instance misidentify modern striae as ancient cut marks, as illustrated by a femur shaft fragment of a medium sized mammal (Fig. 5). The surface damage is characterised by blunt, undefined shoulders that merge into the surrounding bone surface. The modification starts as very shallow striation in a modern break and is interrupted by a modern planar removal of the bone surface. Landeck and Garcia Garriga (2016) interpret this damage as a defleshing cut mark, overlapped by a tooth mark, indicating primary access to carcasses by hominins (Landeck and Garcia Garriga 2016: 58, 63, Fig. 3b). Carnivore damage (cf. (Haynes 1983)) is evident on the edges of the bone fragment (Fig. 5b). 

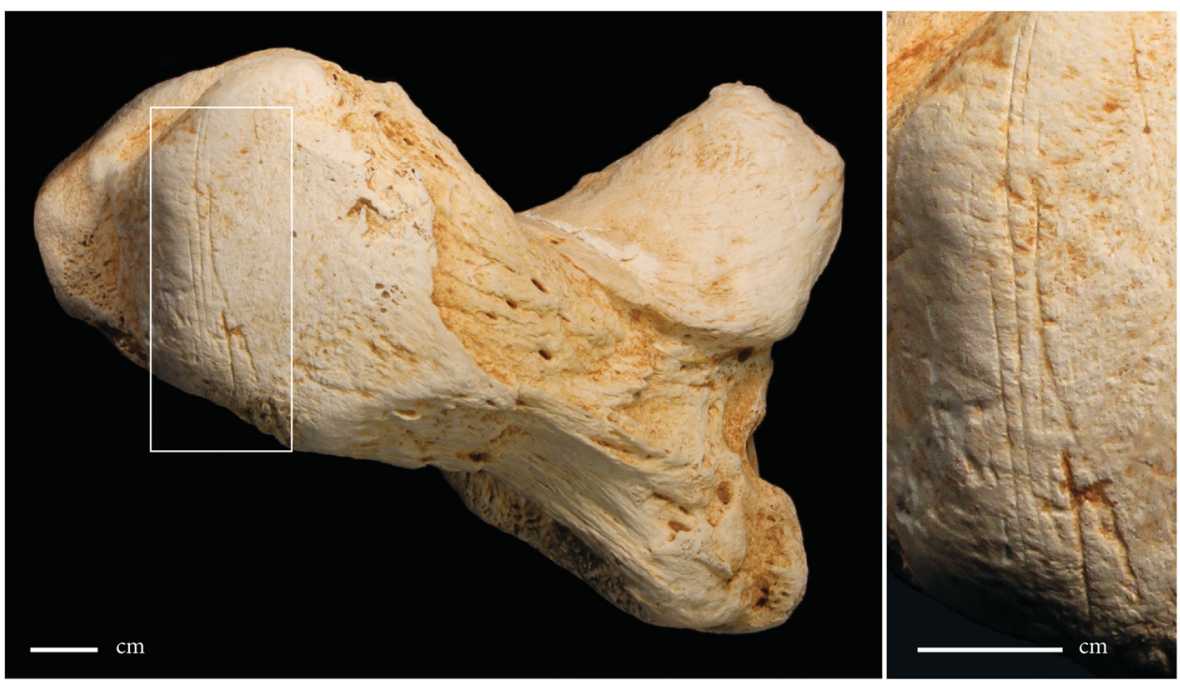

Fig. 6 Left calcaneus of Stephanorhinus hundsheimensis with modern striae, partly filled with red sediment. Landeck and Garcia Garriga published these traces as hominin cut marks providing evidence for the butchery of mega-fauna to obtain muscle meat (Landeck and Garcia Garriga 2016: 58, Fig. 4a)

A left calcaneus of Stephanorhinus hundsheimensis (Fig. 6) with modern striae serves as a further example. Landeck and Garcia Garriga (2016, 58, Fig. 4a) published these traces as hominin cut marks providing evidence for the butchery of mega-fauna to obtain muscle meat. Moreover, rodent modifications were interpreted as being of anthropogenic origin) as exemplified by a right metacarpus of $D$. nestii vallonnetensis (Fig. 7): typical rodent modifications (cf. Fig. 17 in Shipman and Rose 1983) are present on the cranial face of the bone (Fig. 7a), published as traces of skinning by Landeck and Garcia Garriga (2016: 59, Fig. 6c). Additional striae, also published as being indicative of skinning, were located among an amalgam of shallow striae and surface modifications which result from root etching (Fig. $7 \mathrm{~b}$ of Fernández-Jalvo and Andrews 2016). The distal part of the bone also carries modifications caused by root etching and by rodent activities (Fig. 7c). In addition, surface modifications found among an amalgam of traces of similar morphology were isolated in order to argue for the presence of cut marks (our Fig. 7b). In some cases, the published traces could not even be detected on the bones as in the case of a right astragalus of Bison menneri (Landeck and Garcia Garriga 2016, Fig. 6d). Interpretations based on the anatomical location of inferred cut marks are equally problematic. The interpretation of cut marks on the posterior plantar tuber calcanei of the rhino S. hundsheimensis (our Fig. 6) (Landeck and Garcia Garriga 2016: 58, Fig. 4a) and on the diaphysis of a metapodial (Landeck and Garcia Garriga 2016: 58, Fig. 4e) as resulting from the exploitation of muscle meat is anatomically incorrect, since no muscle meat is present there nor can adjacent meat be detached by cutting at these locations. In brief, the claims made regarding the presence of faunal remains indicative of hominin butchering activities at Untermassfeld are unsubstantiated. 

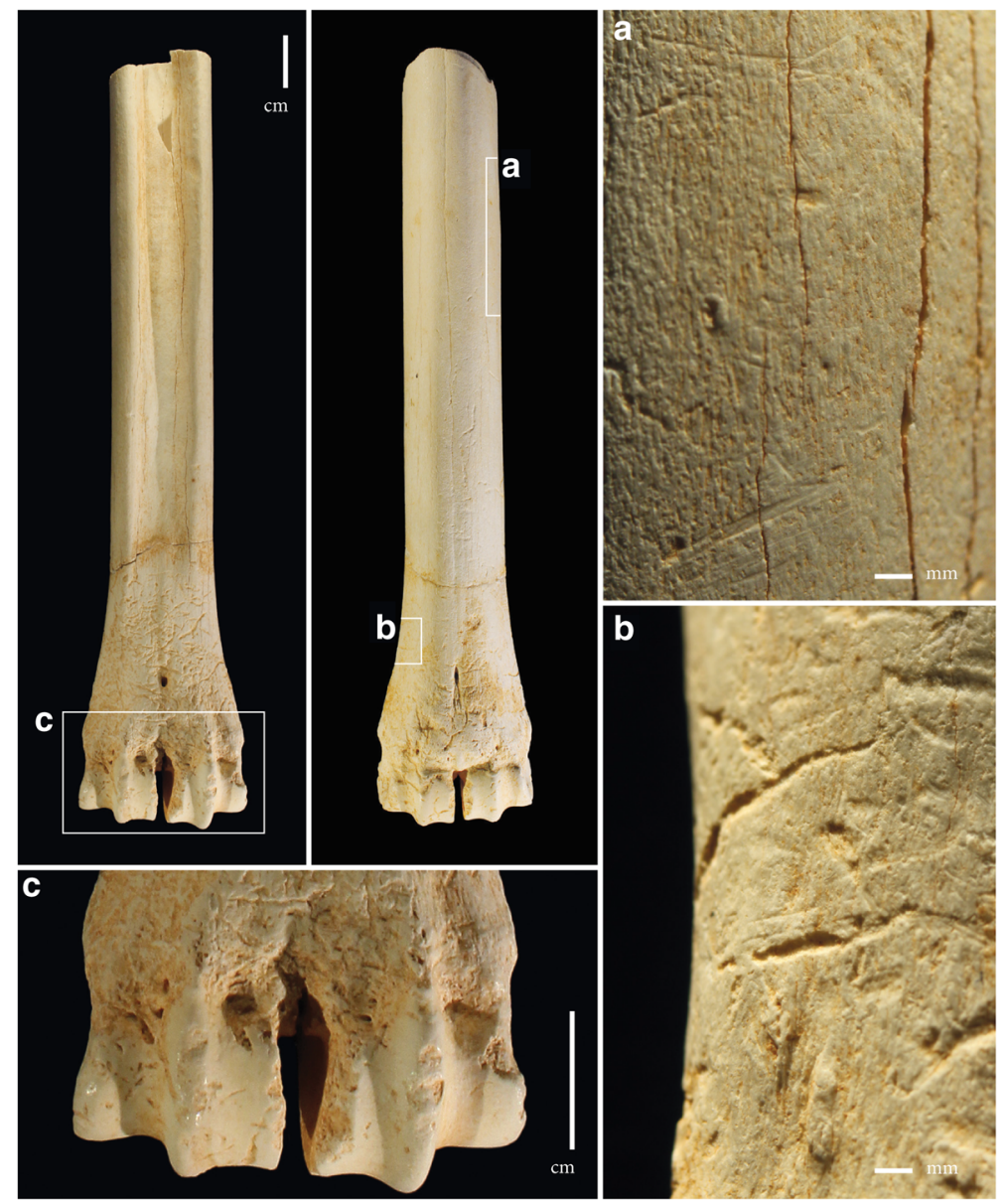

Fig. 7 Right metacarpus of Dama nestii vallonnetensis. a Typical rodent modifications could be observed on the cranial face of the bone, published as traces of skinning (Landeck and Garcia Garriga 2016: 59, Fig. 6c). b Additional striae, also published as being indicative of skinning, were located among an amalgam of shallow striae and surface modifications due to root etching. $\mathbf{c}$ The distal part of the bone carries modifications due to root etching and rodents

\section{Lithics}

According to Landeck and Garcia Garriga, the inferred access to large mammal carcasses was facilitated through the use of "mode 1" small microlithic tools (average length of retouched flakes $19.1 \mathrm{~mm}$, of flakes $22.8 \mathrm{~mm}$ ), which were produced in "short chaînes opératoires" using a systematised bipolar on an "anvil knapping technique" and made on material "locally sourced from nearby streams and outcrops" (2013: 7778). The unknown provenance and whereabouts of the small assemblage have already been addressed above. The packages with the faunal remains delivered to the Schleusingen museum also contained 11 small rock fragments, all published as artefacts by Garcia Garriga et al. (2013: their Figs. 5a, c-e, 6a-d, and 7c-e) and momentarily stored at the Senckenberg Research Station of Quaternary Palaeontology, Weimar. There are six chert (Hornstein) fragments and five limestone pieces, all sourceable 


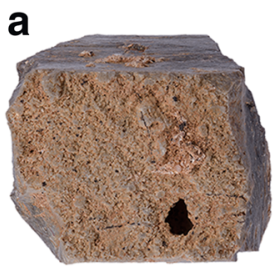

b

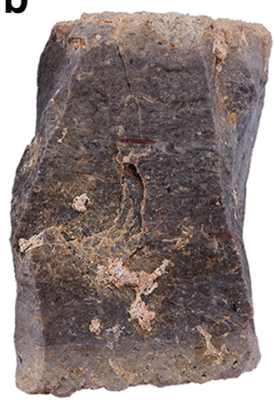

d

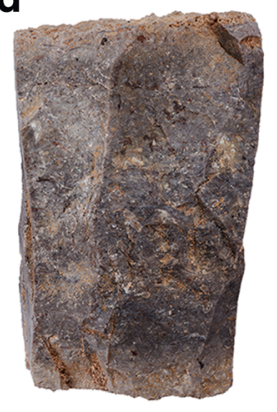

e

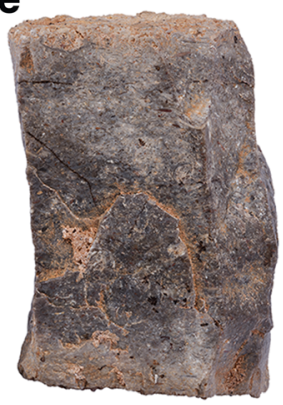

f

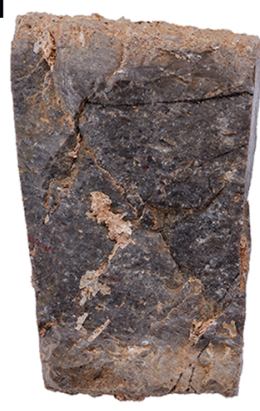

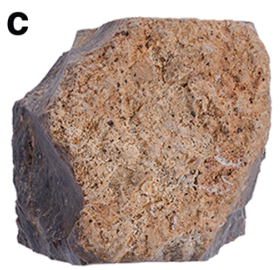

Fig. 8 Chert fragment, published as a "tabular chert core knapped on an anvil" (Garcia Garriga et al. 2013: Fig. 5e)

to the local Triassic Muschelkalk deposits. To illustrate the character of these finds, we refer the reader to the original publication by Garcia Garriga et al. (2013), with pictures of the objects, six of which we publish here too. Our Figs. 8, 9, and 10 show objects interpreted as cores "knapped on an anvil": our Fig. 8 illustrates a broken chert piece, published as a "tabular chert core knapped on an anvil" (Garcia Garriga et al. 2013, Fig. 5e), our Fig. 9 displays various views of a "pyramidal chert core," with cortical remains (compare Fig. 5a in Garcia Garriga et al. 2013, only $22 \mathrm{~mm}$ in its largest dimension - and published with an incorrect scale bar), while Fig. 10 shows another inferred core (compare Fig. 5c in Garcia Garriga et al. 2013). The objects illustrated in our Figs. 11, 12, and 13 are interpreted by Garcia Garriga et al. (2013) as flakes. Figure 11 shows a shattered limestone piece, with no bulbus, no platform, no retouch, and with irregularly crushed edges, originally described as displaying "regular and continuous retouches at a steep angle" (Garcia Garriga et al. 2013: 81 and Fig. 7e). The lithic fragments displayed in Figs. 12 and 13 (Garcia Garriga et al. 2013: Figs. 6b and d) have been published as chert flakes produced in a "bipolar on an anvil technique." Not one of the 11 pieces has a clearly visible bulb of percussion, while a co-occurrence of a definable striking platform with scars of previous removals is also absent. The authors' own statement that part of the assemblage consists of "... pieces of shatter or chunks which lack characteristic fracture propagation characteristics" (Landeck 2008) certainly applies to these 11 pieces, that in our view need to be interpreted as clear geofacts (cf. Wiśniewski et al. 2014). As detailed elsewhere (Ellenberg and Kahlke 


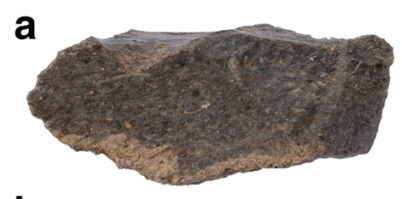

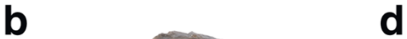

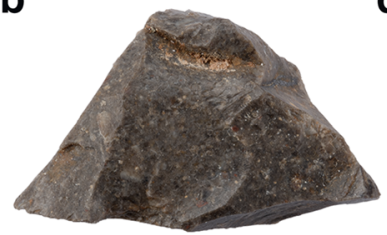

C

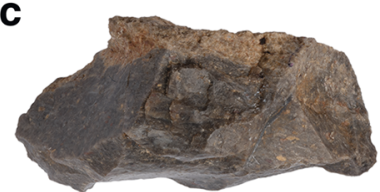

e

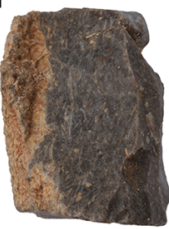

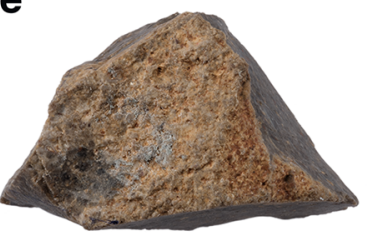

f

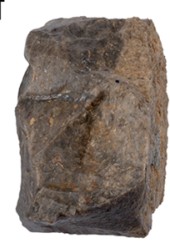

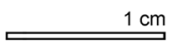

Fig. 9 Chert fragment published as a "pyramidal chert core" with cortical remains (compare Fig. 5a in Garcia Garriga et al. 2013), only $22 \mathrm{~mm}$ in its largest dimension

1997; Kahlke 2006) and as mentioned above, the find bearing sands contain large amounts of Middle Triassic limestone debris in the form of chert and limestone fragments from the river valley slopes upstream and in the vicinity of the site, as well from the coarse clastic mudflow fan which moved downward from the slope into the fluvial deposits (Fig. 2). These fragments are in the same size range and of the same facies and morphology as the "small artefacts" published by Garcia Garriga et al. (2013) and are very abundant in the find bearing deposits. To illustrate this, our Fig. 14 shows two boxes with such rock fragments retrieved during preparation of a sediment block of approximately $50 \times 35 \times 25 \mathrm{~cm}$, containing the skull of a juvenile hyena,

\section{a}

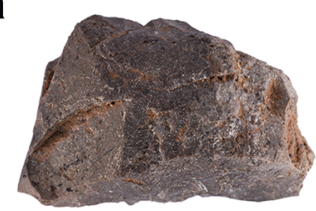

b
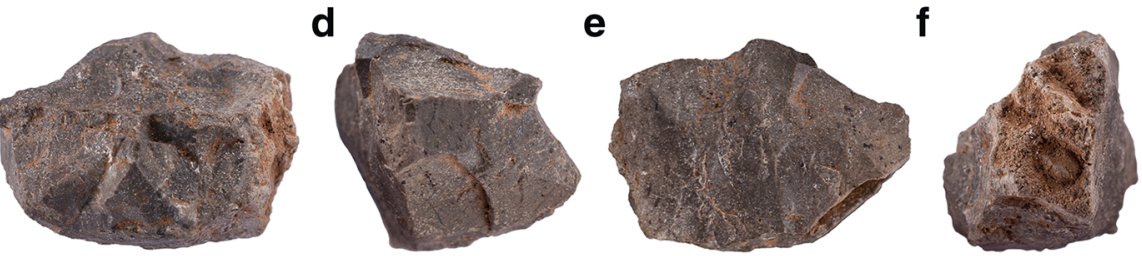

C

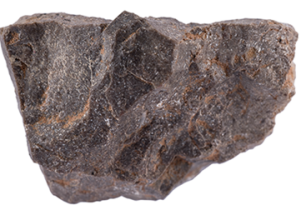

$1 \mathrm{~cm}$

Fig. 10 Silicified limestone fragment interpreted as a core "knapped on an anvil" (compare Fig. 5c in Garcia Garriga et al. 2013) 
a

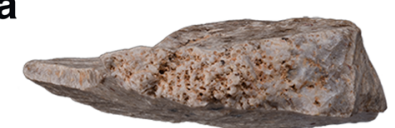

b

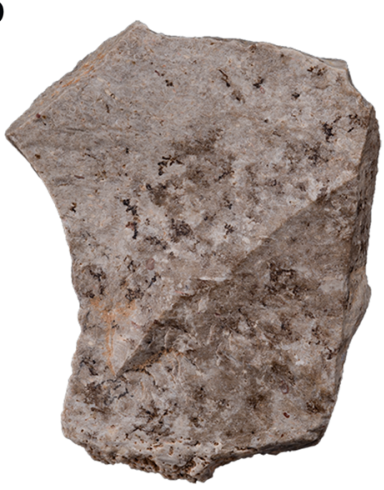

d

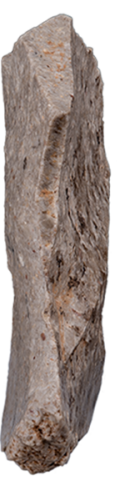

e

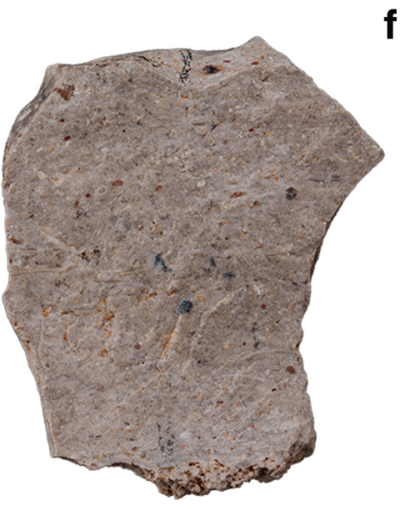

$\mathbf{f}$

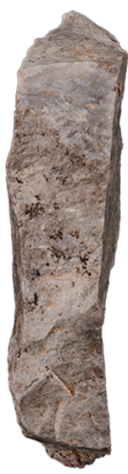

C

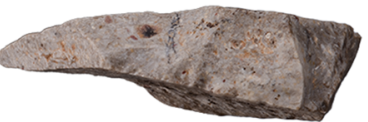

$1 \mathrm{~cm}$

Fig. 11 Limestone fragment, with no bulbus, no platform, no retouch, and with irregularly crushed edges, described by Garcia Garriga et al. (2013: 81) as displaying "regular and continuous retouches at a steep angle" (their Fig. 7e)

Pachycrocutra brevirostris, excavated in 1993, likewise illustrated in our Fig. 14. The figure underlines the abundant presence of shattered pieces of limestone and chert in the find bearing deposits (as well as the careful documentation, preparation, and storage of all finds from the Untermassfeld site).

a

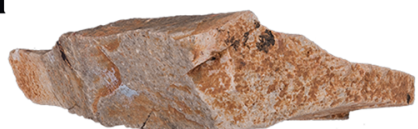

b

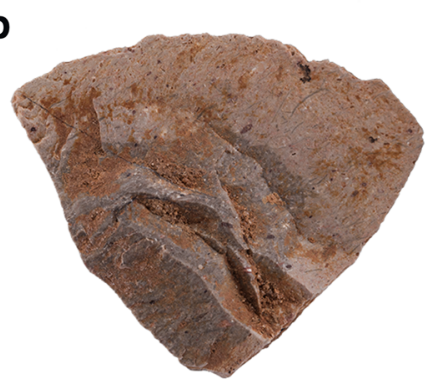

C

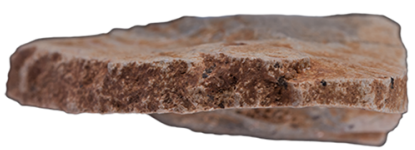

d
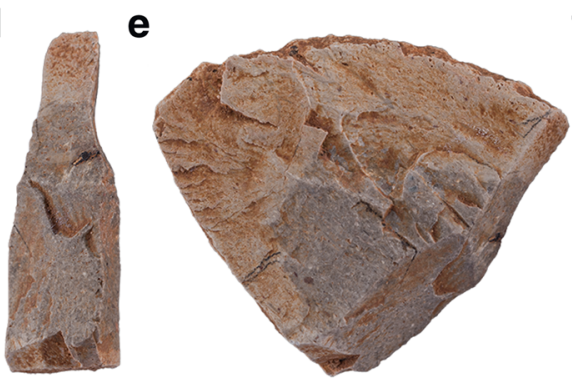

$\mathbf{f}$

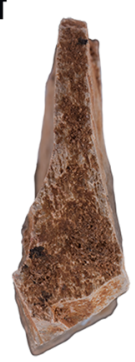

$1 \mathrm{~cm}$

Fig. 12 Chert fragment, interpreted as a flake produced in a "bipolar on an anvil technique" (compare Fig. 6b in Garcia Garriga et al. 2013) 

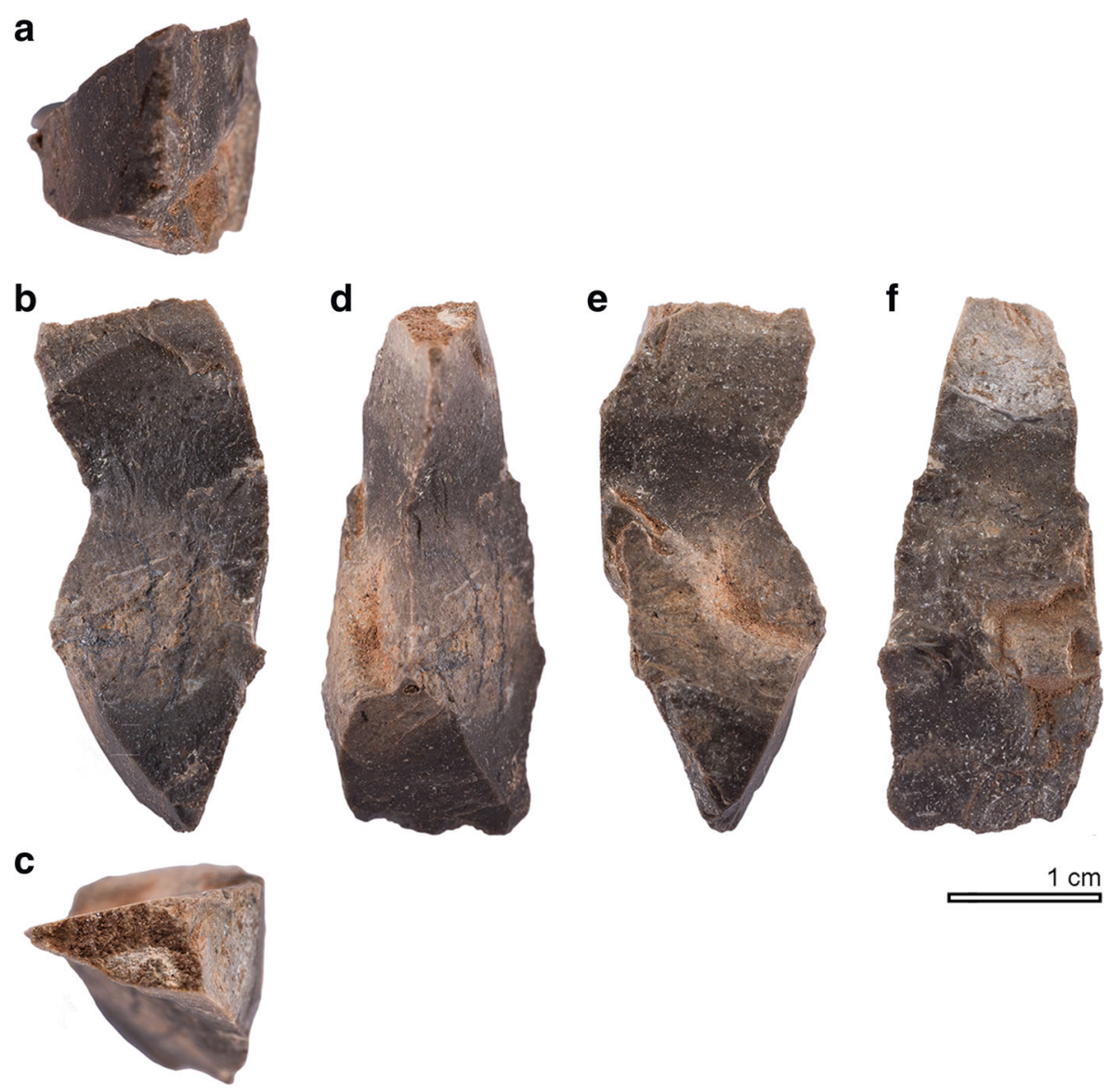

Fig. 13 Chert fragment, interpreted as a flake produced in a "bipolar on an anvil technique" (compare Fig. 6d in Garcia Garriga et al. 2013)

Summarising, the find location(s) of the lithic fragments published by Garcia Garriga and colleagues is undocumented and unknown, but the 11 pieces available perfectly fit within the natural background of shattered pieces from the Muschelkalk deposits both within and above the Untermassfeld find bearing deposits, both in terms of their raw materials as well the natural modifications observable on these natural background objects (Fig. 14). We conclude that the lithic pieces do not testify to any form of hominin modification, the lithic assemblage simply being the result of selecting naturally broken pieces from locally occurring deposits or from comparable adjacent outcrops in the Werra valley.

\section{Discussion}

\section{The Untermassfeld Case}

In summary, the studies claiming an early hominin presence at Untermassfeld are severely flawed in terms of data on provenance of the materials said to 


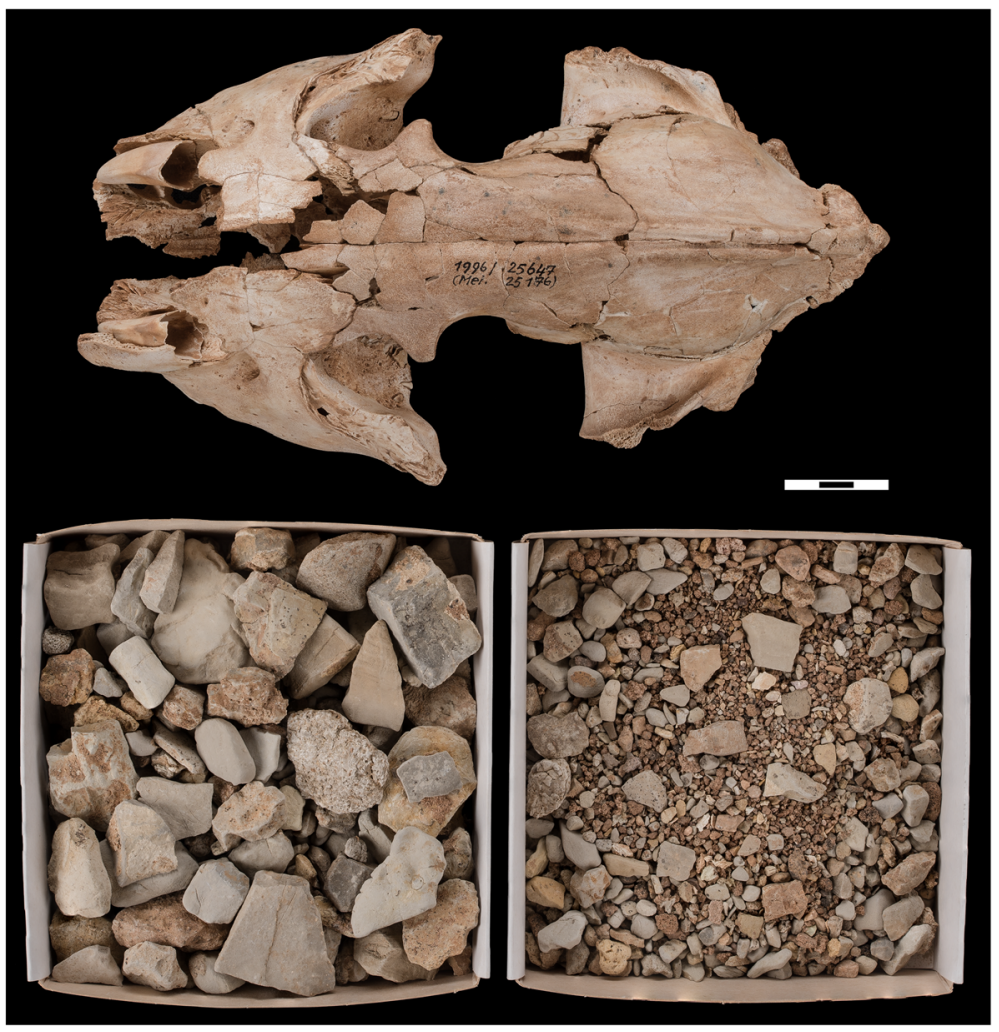

Fig. 14 Untermassfeld, boxes with debris of Triassic limestone and chert, collected during preparation of a sediment block $(50 \times 35 \times 25 \mathrm{~cm})$ containing the fragmentary skull of a juvenile hyaena (Pachycrocuta brevirostris), excavated 21 July 1993 from squares 921 and 922, 0.40-0.50 cm above 0-level of the site (for exact find position see Kahlke 2006, foldout XIII), inventory number IQW 1996/25 647 (Mei. 25 176) (scale $3 \mathrm{~cm})$

have been studied and in terms of (absence of) information on where the material is deposited. At least one of the faunal remains does come from the site, but the provenance of the lithics is completely unknown. The sample of faunal remains and lithics that we were able to study does not show any traces of hominin interference and does not testify to a hominin presence at the site. We have no idea where the rest of the assemblage allegedly studied by Garcia Garriga and colleagues is stored and hence what it looks like, but based on the published finds that we were able to evaluate, Untermassfeld is not an archaeological site. As mentioned above, the Untermassfeld project has from the very beginning taken into consideration a possible presence of traces of hominin activities (Kahlke 1997, 2006), but more than three decades of fieldwork at the site, with 90 months of excavations there, as well as subsequent laboratory analyses by a wide range of specialists, so far did not yield any indication of a hominin presence in the fossil bearing deposits, not in terms of lithic artefacts, nor in hominin modifications of faunal remains. To clean up the record of the Early Pleistocene occupation of Europe, Untermassfeld should not be considered an archaeological site. 


\section{Beyond Untermassfeld}

Now more than two decades ago, the so-called Short Chronology (Roebroeks and van Kolfschoten 1994) pushed for a critical evaluation of the record for the earliest occupation of Europe, in a large-scale evaluation of both dating evidence as well as evidence for the hominin workmanship of the lithic industries from the earliest sites (Roebroeks and van Kolfschoten 1995). The Short Chronology also questioned the artifactual character of lithics from inferred early archaeological sites such as Kärlich (Germany) (Bosinski et al. 1980; Vollbrecht 1997), Přezletice (Czechia) (Fridrich and Sklenář 1989), or Le Vallonnet in France (de Lumley et al. 1988). It suggested that these assemblages displayed all the characteristics of a selection of "primitive" pieces picked out from a matrix rich in rocks and pebbles, without any clear evidence for human agency at the sites - an issue that has been at stake in Palaeolithic archaeology since the days of the "eolith" controversies in the first decades of the twentieth century, whose main lesson was elegantly summarised by Warren (1920), in a quote which is still highly topical almost a century later:

What is important, however, is the fact that such phenomena as the flaking of flints and occasional bulbs and also edge-knapping are produced by causes entirely apart from direct human effort. The likeness between the flaking produced by Nature and that produced by human agencies is sufficient to shift any burden of proof upon those who maintain the human origin of the stones; and this must be done not by a careful selection of picked specimens, but by a survey of the whole group (Warren 1920, 250).

The main conclusion of the Short Chronology was that most, if not all, the earliest published sites were either poorly dated or had lithics that were not of human manufacture, and that the oldest well-dated sites with artefacts were from around $500 \mathrm{ka}$ or younger, suggesting a shift in the dynamics of occupation of this part of the Old World from around half a million years ago onward. The work set a rigorous standard against which new sites could be tested. The hypothesis however was falsified by new evidence from the Atapuerca TD sequence (Carbonell et al. 1995), with finds older than $800 \mathrm{ka}$, that passed the test and led to modification of the original model (Dennell and Roebroeks 1996). For northern Europe, the threshold of 500-600 ka still held firm until new sites were discovered in the UK with evidence from Pakefield at 600-700 ka (Parfitt et al. 2005; Roebroeks 2005) and even older from Happisburgh Site 3 (Ashton et al. 2014; Parfitt et al. 2010). It is important to underline that the hypothesis was falsified by new data from new sites as a result of new fieldwork, in the case of the Atapuerca TD sequence even explicitly aimed at falsifying the hypothesis (Carbonell et al. 1999), and not by new data from contested early sites, such as the ones mentioned above.

Solid data points (sites) are important, as depending on the selection of "acceptable" sites, different scenarios emerge. Published scenarios include claims for a very early occupation of Europe, at about 1.4-1.5 Ma, on the basis of lithic materials from a few sites in southern Europe, such as Pirro Nord in southern Italy (López-García et al. 2015; Pavia et al. 2012) and lithic assemblages from exposures in the Guadix-Baza area near 
Orce in southern Spain (Scott et al. 2007; Toro-Moyano et al. 2013). These finds would imply a hominin presence in Europe close in time to the earliest traces of a hominin presence in western Asia, at Dmanisi (Georgia) at the gates of Europe (Ferring et al. 2011), but it needs to be stressed that the dating methods on which such claims are based are associated with large uncertainties (Muttoni et al. 2013, 2015). Well-dated unambiguous archaeological sites are significantly younger, suggestive of a significant (>700,000 years) time lag between the Dmanisi finds and a post-Jaramillo first appearance of hominins in Europe, possibly prompted by profound environmental changes resulting from the high amplitude glacial oscillations of the late Early Pleistocene, around $900 \mathrm{ka}$ (Muttoni et al. 2015). Also on a smaller spatiotemporal scale, within Europe itself, tracking the presence and absence of hominins through time and in specific areas is an interesting exercise, as such differential occupation patterns are potentially very informative on hominin environmental limits and preferences (Cohen et al. 2012; Wiśniewski et al. 2014).

Fuelled by these issues, the database for early Europe is under constant maintenance through the normal process of scientific debate, which from time to time eliminates incorrect data, e.g. regarding the inferred artifactual character of finds (see for example the site Konczyce Wielkie 4 in South Poland (Wiśniewski et al. 2014)) or their age (Álvarez-Posada et al. 2017; Jiménez-Arenas et al. 2011), as well illustrated by the significant rejuvenation of the Ceprano (Italy) calvarium over the last decade by about 400,000 years, from an inferred pre-Brunhes-Matuyama (Manzi et al. 2001) age to the current age estimate of around $400 \mathrm{ka}$ (Muttoni et al. 2009; Manzi et al. 2010) - see also the case of the Isernia site in Italy, which moved from an inferred pre-Brunhes-Matuyama age (Peretto 1991) to well into the Middle Pleistocene (Roebroeks and van Kolfschoten 1994) as recently demonstrated again by ${ }^{40} \mathrm{Ar} /{ }^{39} \mathrm{Ar}$ dating of the site (Peretto et al. 2015).

The site of Untermassfeld has often been mentioned in one line with Vallparadís (Catalonia, Spain), as dating to the same time period and sharing a comparable mode 1 stone industry, “... which allows us to hypothesise that human groups with the same technology and acting as predators spread throughout the continent from the Jaramillo subchron onwards" (Garcia Garriga et al. 2013, 73). As at Untermassfeld, the primitive lithic assemblage from Vallparadis has been selected from stone rich (alluvial fan) deposits (Garcia Garriga et al. 2012; Martínez et al. 2010). Some of the excavators of the Vallparadís site however explicitly question the artefactual character of the lithics presented by Martinez and colleagues (2010), stressing that the morphology of the lithics and the sedimentological data from the Vallparadís site do not support an anthropogenic origin of the recovered lithic pieces: they are not in primary context, fit very well in the general background of the lithic source area, and generally display rounded edges that cannot be accounted for by (the inferred) transport during a mudflow event (Madurell-Malapeira et al. 2012).

Issues regarding provenance, (non-) artefactual character and age of the "Oldowan" lithic assemblage from Vallparadis and other inferred early "archaeological sites" have been debated repeatedly in the last years (Garcia Garriga et al. 2012; MadurellMalapeira et al. 2012; Muttoni et al. 2013, 2015), with Muttoni and colleagues recently concluding that currently " ... there is no compelling chronological evidence of hominin presence before or during the Jaramillo" in Europe (Muttoni et al. 2015, 188).

The quality of the sites we put on our distribution maps matters, and hence database hygiene is crucial. The examples given above illustrate that there does exist an open 
debate that contributes to database maintenance in our field. In some prominent other cases, one can observe a persistent absence of debate though. Once sites are in the scientific literature, claims can have very long half-lives. The French cave site of Le Vallonnet (de Lumley et al. 1988) is still a very prominent one in studies of early Europe, routinely treated as an archaeological site from the Jaramillo subchron, even though the palaeomagnetic dating evidence is debated (Muttoni et al. 2013; Parés et al. 2013). A recent dating study of the infill suggests that the site pre-dates the Jaramillo and gives an age in the 1.1-1.2-Ma range (Michel et al. 2017). More importantly, the artificial character of the small and primitive (but well-published) lithic assemblage (de Lumley et al. 1988) from the site is not unambiguous (Roebroeks and van Kolfschoten 1994). The lithics from Le Vallonet (see Michel et al. 2017, Fig. 3 for a clear colour picture of some "lithic artefacts" from the site) were already addressed in the Short Chronology and have also been critically reviewed in another, independent, publication (White 1995):

The evidence for human activity at La Grotte du Vallonet would appear to be based on selection of modified lithic objects, that when examined, demonstrate a remarkable similarity to those from an overlying layer of Miocene conglomerate or 'puddingstone' containing pebbles with natural fractures, that were unmistakably produced millions of years before the first Australopithecines (White 1995:76).

Besides issues regarding the artificial character of the lithics from Le Vallonet (Roebroeks and van Kolfschoten 1994; White 1995), it has also been pointed out that the identification of an inferred bone tool from the site (de Lumley et al. 1988) was not based on taphonomic and contextual analyses of the bone assemblage and that the morphology of the cave (cave ceiling was less than $1 \mathrm{~m}$ above the layer in which the bone tool was found) is not easy to reconcile with a view of the site as a human occupation site (Villa and Bartram 1996). The fact that the explicit questions raised by these publications have never been addressed in papers by the excavators of Le Vallonet, besides a very brief mentioning of their existence in a recent paper (Michel et al. 2017), illustrates that there is still ground to gain for an open scientific debate on the earliest occupation of Europe.

\section{Conclusion}

The absence of any hominin traces whatsoever at the Untermassfeld site and the problematic character of the claims made for sites such as Vallparadis and Le Vallonet imply that at the scale of Europe, solid undisputed evidence for a hominin presence in the Early Pleistocene is indeed rare (Muttoni et al. 2015), suggestive of an intermittent presence, with the earliest sites located at most $40^{\circ}$ north - as is the case across much of Eurasia, from northern Spain (Atapuerca: Carbonell et al. 2008), to Dmanisi in the Georgia (Ferring et al. 2011) all the way to the Nihewan Basin in northern China (Dennell 2013). In the very final part of the Early Pleistocene, hominins, at around 800-900 ka, may have expanded their range temporarily northward, following the 
European coastal areas, when conditions permitted. It is only much later, around $600 \mathrm{ka}$, that the record changes significantly, with an increase in site numbers all over western Europe, suggestive of changes in the character of hominin presence in this part of the world. These archaeological changes occur around the time period of the emergence of the Neanderthal lineage, which can be seen as independentpalaeontological - evidence for continuity of hominin occupation from that time period onward, minimally at the scale of Europe. Neanderthal populations expanded their range eastward, into the central parts of Europe from the middle part of the Middle Pleistocene, $\sim 350 \mathrm{ka}$, onward, incorporating more challenging continental environments (Cohen et al. 2012; Kahlke et al. 2011), an expansion that has been related to the development of new cultural and possibly biological adaptations (Hosfield 2016; MacDonald 2017; Roebroeks and Villa 2011; Shimelmitz et al. 2014).

We need solid data - well-dated sites with unambiguous traces of a hominin presence - to test the strength of the pattern described above, in fact a working hypothesis continuously subjected to testing and refinement by new field- and laboratory studies. In a discipline with limited access to original finds and especially their original context, scientists are heavily depending on the quality of scientific publications and hence on solid peer review. The case of Untermassfeld presented in extenso here underlines that peer review is an imperfect shield and that flawed claims do make their way into the scientific literature. Once such claims are there, it is difficult to withdraw them from the scientific discourse, especially when published in high-impact journals. The Untermassfeld case underlines the importance of very careful peer review and the necessity of detailed description of the provenance of published materials as well where they are deposited for other researchers to access (see also Gramling 2016).

A more general question is how to deal with disputed sites in the literature on earliest Europe. The claims for contested sites like Přezletice or Le Vallonet, for instance, have not become more valid because of the rich and well-documented finds from contemporaneous late Early and early Middle Pleistocene deposits in the Atapuerca site complex in Spain. This is not only an issue of the chronology of early occupation but also about establishing the character of early occupation of a given area-continuous or discontinuous (MacDonald et al. 2012) — and the environmental tolerances and preferences of the early occupants of Eurasia. Chronology is crucial if we want to establish what triggered colonisation of the various areas of Eurasia, under which circumstances various areas became populated and subsequently depopulated after earlier colonisation, and whether spatiotemporal patterns of occupation correlate with new biological and/or cultural adaptations.

An open scientific debate is the most powerful tool to clean up and maintain our database, and that sometimes involves presenting negative evidence, as we have done here: Untermassfeld is not an archaeological site. Which site is next?

Acknowledgements The authors are grateful to N. Bicho (Faro), N.J. Conard (Tübingen), R. Klein (Stanford), S. McPherron (Leipzig), M.D. Petraglia (Oxford/Jena), and E. Pop (MONREPOS/Leiden) as well as to two PLoS One (including M. Mussi, Rome) and three Journal of Paleolithic Archaeology reviewers for commenting upon an earlier draft of the paper. R.-D. K. thanks J.-A. Keiler (Weimar) for the compilation of data on the thefts at the Untermassfeld excavation site, as well as for years of cooperation with the responsible police authorities and the Thuringian State Office for Monument Preservation and Archaeology. Further thanks go to S. Döring, E. Haase and T. Korn (all Weimar), to E. Noack and N. Viehöver (both MONREPOS), as well as to J. Porck (Leiden) for producing the figures. 
This paper has a long history. An earlier version of it was submitted in the summer of 2016 as a News and Views article to the Journal of Human Evolution as a reaction on the Landeck and Garcia Garriga 2016 paper published in that journal (Landeck and Garcia Garriga 2016). Months after submission, the Journal of Human Evolution editors decided not to send our paper out for review, as we refused to follow their request to strike a section dealing with the problematic provenance history of the assemblage studied by Garcia Garriga and Landeck. We consider that provenance history to be an important part of the context of the study by Garcia Garriga and Landeck, including that the whereabouts of almost all the faunal material published in the Journal of Human Evolution is unknown, not deposited in a museum or other repository, and not accessible for other researchers. We withdrew the paper from the Journal of Human Evolution and submitted a new version to PLOS ONE. After almost 8 months with PLOS ONE and after a positive Academic Review the Staff Editors of that journal likewise requested us to remove "... the discussion about provenance of the samples and any language implying inappropriate conduct, as this is beyond the scientific discussion of the samples themselves." In this unfortunate case, however, the provenance history is key to the scientific research and discussion. On October 30th 2017 we submitted the paper to the pre-print server BioRxiv.org, where it went online on October 31th: https://www.biorxiv.org/content/early/2017/10/31/211268. Ten days later, the journal Quaternary International published an "expression of concern" for two of their papers on Untermassfeld (Garcia Garriga et al. 2013 as well as Landeck and Garcia Garriga 2017). The Journal of Human Evolution followed three days later, issuing an expression of concern for their publication of Landeck and Garcia Garriga (2016), http://www.sciencedirect.com/science/article/pii/S0047248417304633: “...In the opinion of the journal, the location where the material was housed was not stated accurately in the publication, and its accessibility for further study cannot be verified. The authors were asked to clarify the current location of all the material published, but they have been unable to do so adequately. This makes the veracity of provenience and modification claims difficult to verify in future research".

Open Access This article is distributed under the terms of the Creative Commons Attribution 4.0 International License (http://creativecommons.org/licenses/by/4.0/), which permits unrestricted use, distribution, and reproduction in any medium, provided you give appropriate credit to the original author(s) and the source, provide a link to the Creative Commons license, and indicate if changes were made.

\section{References}

Álvarez-Posada, C., Parés, J. M., Sala, R., Viseras, C., \& Pla-Pueyo, S. (2017). New magnetostratigraphic evidence for the age of Acheulean tools at the archaeo-palaeontological site "Solana del Zamborino" (Guadix-Baza Basin, S Spain). Scientific Reports, 7(1), 13495.

Ashton, N., \& Lewis, S. G. (2012). The environmental contexts of early human occupation of northwest Europe: the British lower Palaeolithic record. Quaternary International, 271, 50-64.

Ashton, N., Lewis, S.G., De Groote, I., Duffy, S.M., Bates, M., Bates, R., Hoare, P., Lewis, M., Parfitt, SA., Peglar, S. et al. (2014). Hominin footprints from Early Pleistocene deposits at Happisburgh, UK. PLoS One, $9(2)$.

Baales, M. (2014). Untermassfeld - or the struggle for finding the earliest traces of human occupation in Central Europe: a comment on:"Hominin dispersals from the Jaramillo subchron in central and southwestern Europe: Untermassfeld (Germany) and Vallparadís (Spain)” by J. Garcia et al., Quaternary International 316 (2013), pp. 73-93. Quaternary International, 337, 254-256.

Bermúdez de Castro, J. M., Martinón-Torres, M., Gómez-Robles, A., Prado-Simón, L., Martín-Francés, L., Lapresa, M., Olejniczak, A., \& Carbonell, E. (2011). Early Pleistocene human mandible from Sima del Elefante (TE) cave site in Sierra de Atapuerca (Spain): a comparative morphological study. Journal of Human Evolution, 61(1), 12-25.

Bermúdez de Castro, J. M., Martinón-Torres, M., Rosell, J., Blasco, R., Arsuaga, J. L., \& Carbonell, E. (2016). Continuity versus discontinuity of the human settlement of Europe between the late Early Pleistocene and the early Middle Pleistocene. The mandibular evidence. Quaternary Science Reviews, 153, 51-62.

Blumenschine, R. J., \& Selvaggio, M. M. (1988). Percussion marks on bone surfaces as a new diagnostic of hominid behaviour. Nature, 333(6175), 763-765.

Blumenschine, R. J., \& Selvaggio, M. M. (1991). On the marks of marrow bone processing by hammerstones and hyenas: their anatomical patterning and archaeological implications. In J. D. Clark (Ed.), Cultural beginnings: approaches to understanding early hominid life-ways in the African savannah (pp. 17-32). Bonn: Rudolf Habelt. 
Bosinski, G., Brunnacker, K., Lanser, K. P., Stephan, S., Urban, B., Würges, K. (1980). Altpaläolithische Funde von Kärlich, Kreis Mayen-Koblenz (Neuwieder Becken). Archäologisches Korrespondenzblatt, 10, 295-314.

Bunn, H.T. (1982). Meat eating and human evolution: studies of the diet and subsistence patterns of PlioPleistocene hominids in East Africa. Berkeley: Ph.D. dissertation, Department of Anthropology, University of California.

Carbonell, E., Bermúdez de Castro, J. M., Arsuaga, J. L., Díez, J. C., Rosas, A., Cuenca-Bescós, G., Sala, R., Mosquera, M., \& Rodríguez, X. P. (1995). Lower Pleistocene hominids and artifacts from Atapuerca-TD6 (Spain). Science, 269 (5225), 826-830.

Carbonell, E., Bermúdez de Castro, J. M., Parés, J. M., Pérez-González, A., Cuenca-Bescós, G., Ollé, A., Mosquera, M., Huguet, R., van der Made, J., Rosas, A., et al. (2008). The first hominin of Europe. Nature, 452(7186), 465-470.

Carbonell, E., Esteban, M., Martín, A., Nájera, A. M., Mosquera, M., Rodríguez, X. P., Ollé, A., Sala, R., Vergès, J. M., Bermúdez de Castro, J. M., et al. (1999). The Pleistocene site of Gran Dolina, Sierra de Atapuerca, Spain: a history of the archaeological investigations. Journal of Human Evolution, 37(3-4), 313-324.

Cohen, K. M., MacDonald, K., Joordens, J. C. A., Roebroeks, W., \& Gibbard, P. L. (2012). The earliest occupation of north-west Europe: a coastal perspective. Quaternary International, 271, 70-83.

Conard, N. J., Serangeli, J., Böhner, U., Starkovich, B. M., Miller, C. E., Urban, B., \& van Kolfschoten, T. (2015). Excavations at Schöningen and paradigm shifts in human evolution. Journal of Human Evolution, 89, 1-17.

Dennell, R. (2003). Dispersal and colonisation, long and short chronologies: how continuous is the Early Pleistocene record for hominids outside East Africa? Journal of Human Evolution, 45(6), 421-440.

Dennell, R. W. (2013). The Nihewan Basin of North China in the Early Pleistocene: continuous and flourishing, or discontinuous, infrequent and ephemeral occupation? Quaternary International, 295, 223-236.

Dennell, R. W., Martinón-Torres, M., \& Bermúdez de Castro, J. M. (2010). Out of Asia: the initial colonisation of Europe in the Early and Middle Pleistocene. Quaternary International, 223-224, 439-439.

Dennell, R. W., Martinón-Torres, M., \& Bermúdez de Castro, J. M. (2011). Hominin variability, climatic instability and population demography in Middle Pleistocene Europe. Quaternary Science Reviews, 30(11-12), 1511-1524.

Dennell, R., \& Roebroeks, W. (1996). The earliest colonization of Europe: the short chronology revisited. Antiquity, 70(269), 535-542.

Domínguez-Rodrigo, M., \& Barba, R. (2006). New estimates of tooth mark and percussion mark frequencies at the FLK Zinj site: the carnivore-hominid-carnivore hypothesis falsified. Journal of Human Evolution, 50(2), 170-194.

Ellenberg, J., \& Kahlke, R.-D. (1997). Die quartärgeologische Entwicklung des mittleren Werratals und der Bau der Unterpleistozänen Komplexfundstelle Untermassfeld. In R.-D. Kahlke (Ed.), Das Pleistozän von Untermaßfeld bei Meiningen (Thüringen) Teil 1 Monographien des Römisch-Germanischen Zentralmuseums 40,1 (pp. 29-62). Bonn: Habelt.

Fernández-Jalvo, Y., \& Andrews, P. (2016). Atlas of taphonomic identifications. 1001+ images of fossil and recent mammal bone modification. New York: Springer.

Ferring, R., Oms, O., Agusti, J., Berna, F., Nioradze, M., Shelia, T., Tappen, M., Vekua, A., Zhvania, D., \& Lordkipanidze, D. (2011). Earliest human occupations at Dmanisi (Georgian Caucasus) dated to 1.85$1.78 \mathrm{Ma}$. Proceedings of the National Academy of Sciences of the United States of America, 108(26), $10432-10436$.

Fridrich, J., \& Sklenár̆, K. (1989). Přezletice: a lower Palaeolithic site in central Bohemia: (excavations 1969-1985). Prague: Museum Nationale Pragae.

Garcia Garriga, J., Landeck, G., Martínez, K., \& Carbonell, E. (2013). Hominin dispersals from the Jaramillo subchron in central and south-western Europe: Untermassfeld (Germany) and Vallparadís (Spain). Quaternary International, 316, 73-93.

Garcia Garriga, J., Martínez, K., Carbonell, E., Agustí, J., \& Burjachs, F. (2012). Defending the early human occupation of Vallparadís (Barcelona, Iberian Peninsula): a reply to Madurell-Malapeira et al. (2012). Journal of Human Evolution, 63(3), 568-575.

Gillespie, J. D., Tupakka, S., \& Cluney, C. (2004). Distinguishing between naturally and culturally flaked cobbles: a test case from Alberta, Canada. Geoarchaeology, 19(7), 615-633.

Gramling, C. (2016). 'Four-legged snake' may be ancient lizard instead. Science, 354(6312), 536-537.

Haynes, G. (1983). A guide for differentiation mammalian carnivore taxa responsible for gnaw damage to herbivore limb bones. Paleobiology, 9(2), 173-182. 
Hemmer, H. (2006). Pleistocene interregional faunal correlations, Linear Pottery Culture and East-West mediation-80th birthday of Hans-Dietrich Kahlke. Courier Forschungsinstitut Senckenberg, 256, 1-9.

Hosfield, R. (2016). Walking in a winter wonderland? Strategies for Early and Middle Pleistocene survival in Midlatitude Europe. Current Anthropology, 57(5), 653-682.

Hublin, J.-J., \& Roebroeks, W. (2009). Ebb and flow or regional extinctions? On the character of Neandertal occupation of northern environments. Comptes Rendus Palevol, 8(5), 503-509.

Jiménez-Arenas, J. M., Santonja, M., Botella, M., \& Palmqvist, P. (2011). The oldest handaxes in Europe: fact or artefact? Journal of Archaeological Science, 38(12), 3340-3349.

Kahlke, R.-D. (Ed.). (1997). Das Pleistozän von Untermassfeld bei Meinigen (Thüringen). Teil 1. Monographien des RGZM 40, 1. Bonn: Habelt.

Kahlke, R.-D. (Ed.). (2001a). Das Pleistozän von Untermaßfeld bei Meiningen (Thüringen). Teil 2. Monographien des RGZM 40, 2. Bonn: Habelt.

Kahlke, R.-D. (Ed.). (2001b). Das Pleistozän von Untermaßfeld bei Meiningen (Thüringen). Teil 3. Monographien des RGZM 40, 3. Bonn: Habelt.

Kahlke, R.-D. (2006). Untermassfeld - a late Early Pleistocene (Epivillafranchian) fossil site near Meiningen (Thuringia, Germany) and its position in the development of the European mammal fauna. British Archaeological Reports, International Series, 1578. Oxford: Archaeopress.

Kahlke, R.-D. (2007). Late Early Pleistocene European large mammals and the concept of an Epivillafranchian biochron. Courier Forschungsinstitut Senckenberg, 259, 265-278.

Kahlke, R.-D. (2009). Les communautés de grands mammiferes du Pléistocene inférieur terminal et le concept d'un biochrone Épivillafranchien. Quaternaire, 20(4), 415-427.

Kahlke, R.-D., García, N., Kostopoulos, D. S., Lacombat, F., Lister, A. M., Mazza, P. P. A., Spassov, N., \& Titov, V. V. (2011). Western Palaearctic palaeoenvironmental conditions during the Early and early Middle Pleistocene inferred from large mammal communities, and implications for hominin dispersal in Europe. Quaternary Science Reviews, 30(11-12), 1368-1395.

Kahlke, R.-D., \& Gaudzinski, S. (2005). The blessing of a great flood: differentiation of mortality patterns in the large mammal record of the Lower Pleistocene fluvial site of Untermassfeld (Germany) and its relevance for the interpretation of faunal assemblages from archaeological sites. Journal of Archaeological Science, 32(8), 1202-1222.

Landeck G. 2008. Migration of early humans to Central Europe before the Middle Pleistocene? - new archaeological evidence from Germany: http://vorzeit-hessen.com/downloads/migrationofearlyhumanstocentraleurope. pdf. p 23.

Landeck, G. (2010). Further evidence of a Lower Pleistocene arrival of early humans in northern Europe- the Untermassfeld site (Germany). Collegium Anthropologicum, 34(4), 1229-1238.

Landeck, G., \& Garcia Garriga, J. (2015). Jaramillo hominin presence at Untermassfeld (Thuringia, Germany) - or the struggle against the early 20th century "Mauer mandible paradigm": reply to M. Baales (2014). Quaternary International, 355, 169-171.

Landeck, G., \& Garcia Garriga, J. (2016). The oldest hominin butchery in European mid-latitudes at the Jaramillo site of Untermassfeld (Thuringia, Germany). Journal of Human Evolution, 94, 53-71.

Landeck, G., \& Garcia Garriga, J. (2017). New taphonomic data of the 1 Myr hominin butchery at Untermassfeld (Thuringia, Germany). Quaternary International, 436(Part A), 138-161.

Lepre, C. J., Roche, H., Kent, D. V., Harmand, S., Quinn, R. L., Brugal, J.-P., Texier, P.-J., Lenoble, A., \& Feibel, C. S. (2011). An earlier origin for the Acheulian. Nature, 477(7362), 82-85.

López-García, J. M., Luzi, E., Berto, C., Peretto, C., \& Arzarello, M. (2015). Chronological context of the first hominin occurrence in southern Europe: the Allophaiomys ruffoi (Arvicolinae, Rodentia, Mammalia) from Pirro 13 (Pirro Nord, Apulia, southwestern Italy). Quaternary Science Reviews, 107, 260-266.

Lubinski, P. M., Terry, K., \& McCutcheon, P. T. (2014). Comparative methods for distinguishing flakes from geofacts: a case study from the Wenas Creek Mammoth site. Journal of Archaeological Science, 52(Supplement C), 308-320.

de Lumley, H. (1988). La grotte du Vallonnet, Roquebrune-Cap-Martin, Alpes-Maritimes. Situation géographique, description, historique. L'Anthropologie, 92, 387-397.

de Lumley, H., Guerrier, E., Fournier, A., Krzepkowska, J., \& Echassoux, A. (1988). L'industrie du Pléistocène inférieur de la grotte du Vallonnet, Roquebrune-Cap-Martin, Alpes-Maritimes. L'Anthropologie, 92, 501-613.

MacDonald, K. (2017). The use of fire and human distribution. Temperature, 1-13.

MacDonald, K., Martinón-Torres, M., Dennell, R. W., \& Bermúdez de Castro, J. M. (2012). Discontinuity in the record for hominin occupation in south-western Europe: implications for occupation of the middle latitudes of Europe. Quaternary International, 271, 84-97. 
Madurell-Malapeira, J., Alba, D. M., Minwer-Barakat, R., Aurell-Garrido, J., \& Moyà-Solà, S. (2012). Early human dispersals into the Iberian peninsula: a comment on Martinez et al. (2010) and Garcia et al. (2011). Journal of Human Evolution, 62(1), 169-173.

Manzi G., Magri, D., Milli, S., Palombo, M.-R., Margari, V., Celiberti, V., Barbieri, M., Barbieri, M., Melis, R., Rubini, M., Ruffo, M., Saracino, B., Tzedakis, C., Zarattini, A., \& Biddittu, I. (2010). The new chronology of the Ceprano calvarium (Italy). Journal of Human Evolution, 59, 580-585.

Manzi, G., Mallegni, F., \& Ascenzi, A. (2001). A cranium for the earliest Europeans: phylogenetic position of the hominid from Ceprano, Italy. Proceedings of the National Academy of Sciences, 98(17), 1001110016.

Martínez, K., Garcia, J., Carbonell, E., Agustí, J., Bahain, J.-J., Blain, H.-A., Burjachs, F., Cáceres, I., Duval, M., Falguères, C., et al. (2010). A new Lower Pleistocene archeological site in Europe (Vallparadís, Barcelona, Spain). Proceedings of the National Academy of Sciences, 107(13), 5762-5767.

Meyer, M., Arsuaga, J.-L., de Filippo, C., Nagel, S., Aximu-Petri, A., Nickel, B., Martínez, I., Gracia, A., de Castro, J. M. B., Carbonell, E., et al. (2016). Nuclear DNA sequences from the Middle Pleistocene Sima de los Huesos hominins. Nature, 531(7595), 504-507.

Michel, V., Shen, C.-C., Woodhead, J., Hu, H.-M., Wu, C.-C., Moullé, P.-É., Khatib, S., Cauche, D., Moncel, M.-H., Valensi, P., et al. (2017). New dating evidence of the early presence of hominins in southern Europe. Scientific Reports, 7(1), 10074.

Moncel, M.-H., Ashton, N., Lamotte, A., Tuffreau, A., Cliquet, D., \& Despriée, J. (2015). The Early Acheulian of north-western Europe. Journal of Anthropological Archaeology, 40, 302-331.

Moncel, M.H., Despriée, J., Voinchet, P., Tissoux, H., Moreno, D., Bahain, J.J., Courcimault, G., \& Falgueres, C. (2013). Early evidence of Acheulean settlement in northwestern Europe-La Noira Site, a 700 000 year-old occupation in the center of France. PLoS One, 8(11), e75529.

Moncel, M.-H., Landais, A., Lebreton, V., Combourieu-Nebout, N., Nomade, S., \& Bazin, L. (2017). Linking environmental changes with human occupations between 900 and $400 \mathrm{ka}$ in western Europe. Quaternary International. https://doi.org/10.1016/j.quaint.2016.09.065.

Moyano, I. T., Barsky, D., Cauche, D., Celiberti, V., Grégoire, S., Lebegue, F., Moncel, M. H., \& de Lumley, H. (2011). The archaic stone tool industry from Barranco León and Fuente Nueva 3, (Orce, Spain): evidence of the earliest hominin presence in southern Europe. Quaternary International, 243(1), 80-91.

Muttoni, G., Kent, D. V., Scardia, G., \& Martin, R. A. (2015). Bottleneck at Jaramillo for human migration to Iberia and the rest of Europe? Journal of Human Evolution, 80, 187-190.

Muttoni, G., Scardia, G., \& Kent, D. V. (2013). A critique of evidence for human occupation of Europe older than the Jaramillo subchron ( 1 Ma): comment on 'The oldest human fossil in Europe from Orce (Spain)' by Toro-Moyano et al. (2013). Journal of Human Evolution, 65(6), 746-749.

Muttoni, G., Scardia, G., Kent, D. V., Swisher, C. C., \& Manzi, G. (2009). Pleistocene magnetochronology of early hominin sites at Ceprano and Fontana Ranuccio, Italy. Earth and Planetary Science Letters, 286, 255-268.

Nash, D. T. (1993). Distinguishing stone artefacts from naturefacts created by rockfall processes. In P. Goldberg, D. T. Nash, \& M. D. Petraglia (Eds.), Formation processes in archaeological context (pp. 125-138). Madison: Prehistory Press.

Ollé, A., Mosquera, M., Rodríguez, X. P., de Lombera-Hermida, A., García-Antón, M. D., García-Medrano, P., Peña, L., Menéndez, L., Navazo, M., Terradillos, M., et al. (2015). The Early and Middle Pleistocene technological record from Sierra de Atapuerca (Burgos, Spain). Quaternary International, 295, 138-167.

Parés, J. M., Duval, M., \& Arnold, L. J. (2013). New views on an old move: hominin migration into Eurasia. Quaternary International, 295, 5-12.

Parfitt, S. A., Ashton, N. M., Lewis, S. G., Abel, R. L., Coope, G. R., Field, M. H., Gale, R., Hoare, P. G., Larkin, N. R., Lewis, M. D., et al. (2010). Early Pleistocene human occupation at the edge of the boreal zone in northwest Europe. Nature, 466(7303), 229-233.

Parfitt, S. A., Barendregt, R. W., Breda, M., Candy, I., Collins, M. J., Coope, G. R., Durbidge, P., Field, M. H., Lee, J. R., Lister, A. M., et al. (2005). The earliest record of human activity in northern Europe. Nature, 438(7070), 1008-1012.

Pavia, M., Zunino, M., Coltorti, M., Angelone, C., Arzarello, M., Bagnus, C., Bellucci, L., Colombero, S., Marcolini, F., Peretto, C., et al. (2012). Stratigraphical and palaeontological data from the Early Pleistocene Pirro 10 site of Pirro Nord (Puglia, south eastern Italy). Quaternary International, 267, 40-55.

Peacock, E. (1991). Distinguishing between artifacts and geofacts: a test case from eastern England. Journal of Field Archaeology, 18(3), 345-361.

Pereira, A., Nomade, S., Voinchet, P., Bahain, J. J., Falguères, C., Garon, H., Lefèvre, D., Raynal, J. P., Scao, V., \& Piperno, M. (2015). The earliest securely dated hominin fossil in Italy and evidence of Acheulian 
occupation during glacial MIS 16 at Notarchirico (Venosa, Basilicata, Italy). Journal of Quaternary Science, 30(7), 639-650.

Peretto, C. (Ed.) (1991). Isernia la Pineta, Nuovi Contributi Scientifici. Isernia: Instituto Regionale per gli Studi Storici del Molise, V. Cuoco.

Peretto, C., Arnaud, J., Moggi-Cecchi, J., Manzi, G., Nomade, S., Pereira, A., Falguères, C., Bahain, J.-J., Grimaud-Hervé, D., Berto, C., et al. (2015). A human deciduous tooth and new ${ }^{40} \mathrm{Ar} /{ }^{39} \mathrm{Ar}$ dating results from the Middle Pleistocene archaeological site of Isernia La Pineta, southern Italy. PLoS One, 10(10), e0140091.

Potts, R., \& Shipman, P. (1981). Cutmarks made by stone tools on bones from Olduvai Gorge, Tanzania. Nature, 291(5816), 577-580.

Raynal, J.-P., Magoga, L., \& Bindon, P. (1995). Tephrofacts and the first human occupation of the French Massif Central. In W. Roebroeks \& T. van Kolfschoten (Eds.), The earliest occupation of Europe: proceedings of the European Science Foundation Workshop at Tautavel (France), 1993 (pp. 129-146). Leiden: University of Leiden.

Roebroeks, W. (2005). Archaeology: life on the Costa del Cromer. Nature, 438(7070), 921-922.

Roebroeks, W. (2006). The human colonisation of Europe: where are we? Journal of Quaternary Science, $21(5), 425-435$.

Roebroeks, W., \& van Kolfschoten, T. (1994). The earliest occupation of Europe: a short chronology. Antiquity, 68(260), 489-503.

Roebroeks, W., \& van Kolfschoten, T. (1995). The earliest occupation of Europe: proceedings of the European Science Foundation Workshop at Tautavel (France) 1993. Leiden: Leiden University Press.

Roebroeks, W., \& Villa, P. (2011). On the earliest evidence for habitual use of fire in Europe. Proceedings of the National Academy of Sciences, 108(13), 5209-5214.

Rolland, N. (2013). The Early Pleistocene human dispersals in the Circum-Mediterranean Basin and initial peopling of Europe: single or multiple pathways? Quaternary International, 316, 59-72.

Scott, G. R., Gibert, L., \& Gibert, J. (2007). Magnetostratigraphy of the Orce region (Baza Basin), SE Spain: new chronologies for early Pleistocene faunas and hominid occupation sites. Quaternary Science Reviews, 26, 415-435.

Shimelmitz, R., Kuhn, S. L., Jelinek, A. J., Ronen, A., Clark, A. E., \& Weinstein-Evron, M. (2014). 'Fire at will': the emergence of habitual fire use 350,000 years ago. Journal of Human Evolution, 77, 196-203.

Shipman, P., \& Rose, J. (1983). Early hominid hunting, butchering, and carcass-processing behaviors: approaches to the fossil record. Journal of Anthropological Archaeology, 2(1), 57-98.

Toro-Moyano, I., Martínez-Navarro, B., Agustí, J., Souday, C., Bermúdez de Castro, J. M., Martinón-Torres, M., Fajardo, B., Duval, M., Falguères, C., Oms, O., et al. (2013). The oldest human fossil in Europe, from Orce (Spain). Journal of Human Evolution, 65(1), 1-9.

Villa, P. (2001). Early Italy and the colonization of western Europe. Quaternary International, 75, 113-130.

Villa, P., \& Bartram, L. (1996). Flaked bone from a hyena den. Paléo, 8(1), 143-159.

Vollbrecht, J. (1997). Untersuchungen zum Altpaläolithikum im Rheinland. Bonn: Dr. Rudolf Habelt GmbH.

Warren, S. H. (1914). The experimental investigation of flint fracture and its application to problems of human implements. The Journal of the Royal Anthropological Institute of Great Britain and Ireland, 44, 412450.

Warren, S. H. (1920). A natural 'eolith' factory beneath the Thanet Sand. Quarterly Journal of the Geological Society, 76(1-4), 238-253.

White, C. (1995). La Grotte du Vallonet: evidence of early hominid activity or natural processes? Lithics - The Newsletter of the Lithic Studies Society, 16, 70-77.

Wiśniewski, A., Badura, J., Salamon, T., \& Lewandowski, J. (2014). The alleged Early Palaeolithic artefacts are in reality geofacts: a revision of the site of Kończyce Wielkie 4 in the Moravian Gate, South Poland. Journal of Archaeological Science, 52, 189-203. 